\title{
KELÂMî GÖRÜŞLERİ BAĞLAMINDA İBÂZÎLERİN HÂRİCîLİĞİ MESELESİ
}

\author{
Metin YILDIZ \\ Dr. Öğr. Üyesi, Yüzüncüyıl Üniversitesi İlahiyat Fakültesi, Van \\ Assistant Professor, Yüzüncüyıl University Faculty of Theology, Van \\ metinyildiz04@gmail.com \\ orcid.org/0000-0003-3201-862X
}

\begin{abstract}
Öz
Haricîler, Hz. Ali'nin Sıffîn Savaşını hakemlerin görüşlerine başvurarak barışla sonlandırması üzerine tepkisel olarak ortaya çıan ve tahkîmi kabul edenleri tekfîr eden marjinal bir kitledir. Birçok makâlât türü eserde Ezârika, Necedât ve Sufriyya gibi Haricî fırkaların varlığından bahsedildiği gibi İbâzîyye' nin de Hâricî bir fırka olduğu; ama diğerlerine göre daha mu'tedil olduğu ifade edilmektedir. Buna rağmen ilk dönem İbâzî âlimlerden günümüz İbâzîlerine kadar birçok kişi, İbâziyye'nin Haricî bir fırka olmadığını savunmaktadır. İbâzîler şirk ve kendilerine yeni katılan kişileri tanımak amaçlı olarak bir imtihandan geçirme ameliyesi olan isti'raz gibi bazı konularda Haricîlerden farklı görüşlere sahip olmakla birlikte, iman-küfür, tevellâ-teberrâ, imâmet, vb. birçok konuda ise Haricîlerin görüşlerine benzer görüşleri savunmaktadırlar. Diğer Haricî fırkalar zamanla yok olurken araştırma konusu edindiğimiz İbâziyye günümüze kadar varlığını sürdürmüştür. Bu araştırmada İbâzîlerin kelâmî görüşlerini sunmaktan ziyade onların Haricî geleneğin görüşleriyle uyuşan ve farklılaşan görüşlerini tespit etmeye çalışacağız. Bunun neticesinde çalışmamızda bizzat İbâzî kelâm metinlerinden hareketle İbâzîlerin Haricî bir fırka olup olmadığını irdelemeye çalışacağız.
\end{abstract}

Anahtar Kelimeler: Kelâm, Haricîlik, İbâziyye, İman, Küfür, Şirk.

\section{IBĀḌĪS' KHĀRIJISM ISSUE WITH THEIR CONTEXT OF KALĀM IDEAS}

\begin{abstract}
Khārijites is a marginal mass that come up reactively and reacts to whom accepts arbitration (tahkim) upon Caliph 'Alī's end the battle of Șiffin with peace by referring the opinions of referees. As the exixtance of Khārijite sects such as Azāriqa, Najadat, and Sufriyya are mentioned in many works of article type, it is also mentioned that Ibādiyya is an Khārijite sect; but is more moderate than the others. Despite this, many people, from the early Ibāḍi scholars to the present Ibāḍis, argue that Ibāḍism is not an Khārijite group. As well as Ibāḍ̄is have different views from Khārijites in some subjects, such as shirk and isti rād, which is an examination procedure for the purpose of getting to know the new people who are new to them, they believe in the faith. in many cases they defend similar views to the views of the Khārijites such as belief- blasphemy, tawalla-tabarra, imamate etc.. In this study, rather than offering the Kalām thoughts of I Ibādīs, we are going to try to detect their matching and differentiating thoughts with the Khārijite tradition. As a result of this; in our study by acting from the texts of Ibāọi Kalām itself, we are going to try to investigate whether the Ibādīs are a Khārijite group or not.
\end{abstract}

Keywords: Kalām, Khārijism, Ibādism, Faith, Kufr, Shirk.

Atıf/Cite As:, Yıldız, Metin. "Kelâmî Görüşleri Bağlamında İbâzîlerin Hâricîliği Meselesi”. Kader 16/2 (Aralık 2018): 294-318.

Geliş Tarihi: 15.10.2018 Kabul Tarihi: 28.12.2018～Doi: 10.18317/kaderdergi.470922




\section{Summary}

It is possible to classify the Khārijism as two periods that came up after the battle of Siffin as reactive in the period of Caliph 'Ali and declare the ones who accept arbitration (tahkim) as unbelievers. The first period of the Khārijism can be described as "Muhakkima". The outstanding features of this period are calls for compliance with the Qur'an, ideal community work, tribal life, tradition insistence, etc. Their attempts to consubstantiate scientific debates, intellectual struggles and political attitudes with theological issues which started from the sixties of Hijr, in the second period of the Khārijism in Basra, are noteworthy. From these years, the sects like Azāriqa, Najadat, Sufriyya and the Ibādism that we have studied, came up among the Khārijites (Khawārij). Ibāḍis continued their existence until today but the other sects disappeared over time.

Ibāḍism, which gained the name from its founder 'Abdallāh b. Ibāḍ in the first century of Hijr, is the most equable of Khärijite sects and is the only branch of the Khārijite sects to reach our day. Ibāḍiyya, which is mentioned as a sub-branch of Khārijism in the classical Kalām literature, is not accepted as a sub-branch of the Kharijites by many researchers, especially today's Ibādīis. Such that the present day Ibāḍis do not accept the introduction of themselves as Khārijite. They state that they are the continuation of "First Muhakkima", the first nucleus of the Khārijites; but they try to emphasize that they are not the continuation of "Azāriqa". While saying this, they also claim that they are not Khārijī. Although Ibāọī scholars talk about the Khārijī who came up as a result of the events of the period of Caliph 'Alī in a positive way, they transform it into a critical language by changing it from the moment they speak of Nāfi ${ }^{i}$ Ibn al-Azraq (d. 65/685) and depend him. They express that Khārijites have come up after Ibn al-Azraq and they divided into many sects by seperating from people of $(a h l)$ istiqamah sect. They emphasize that Ibn al-Azraq was the first person who opposed the faith of the people of istiqamah, that he disintegrated his congregations by distorting the unity of Muslims, accused the community of qibla with shirk, and that he declared armchair sympathizers who abstained from hijra ( $q a^{\prime} a d a$ ), were to be regarded as outright unbelievers. For Ibāđ̣̄is, Ibn al-Azraq mistaken in these subjects and ruled differently from the rules of Allah. Because Allah has not ruled to take captives and to confiscate their possessions for bagys. When Muslims killed Caliph 'Uthmān, they made nothing halāl other than his blood, did not take captive of his children and seized the goods.

What Ibāạīs mean by the Khārijism word is Azāriqa itself. According to them, Azāriqa, Mārika and Khārijism mean the same. They have accused of shirk all those who are involved in the ahl-qibla and opposed them, they have regarded their blood halāl, they have seen legitimate to take their children and to captive their possessions. Ibāḍis try to put forward a very positive portrait about the Khārijites in the event of arbitration. They report that they did not interfere in their rivals offspring, that they did not see their rivals' property and their honor as halāl for themselves, they did not indiscriminate slaughter of opponents (isti rāa $d$ ), they did not ban anyone from the inheritance, they ruled with justice, everyone felt safe 
in their presence, watched kinship relations, and surrendered their rights to all rights holders. Ibāḍīs differ from extreme Khārijī groups such as Azāriqa in terms of the position of the ones in the world who commited big sin, law and religious qualities.

Ibāḍi authors do not use the sect notions and name the way they follow as religion. They state that the religion they follow is the religion of Allah and the religion followed by the Prophet and the Muslims. The religion of Allah is the religion in which the taxpayers worship Allah with the languages of their prophets. It is emphasized that the religion in the sight of Allah is Islam and that Islam also means obedience, punishment, account and custom. The Messenger of Allah's religion is also the religion of Prophet and there is no difference between the religion of Allah and the religion of the Messenger of Allah. They mean the religion of Muslims, first two Caliphs Abū Bakr and 'Umar and the Ahl-Nehrevān and the Ibādīs follow. According to them, the religion of the people of Nehrevān (ahl-Nehrevan) is the religion of the Prophet, Abū Bakr, 'Umar and Muslims follow. The members of the sects that came up after 'Abdallāh b. Ibād, died dissident to the religion of Ibāọī both in religion, speech, attitude and idea. According to them, there is only one religion, and it is the religion they follow. The followers of other sects are infernal because they are not on religion. There are many presumptions that the Ibādīis are a sub-branch of the Khārijism, although they oppose their selves to be referred to by the Khārijism. In this respect, the Ibāọīs and other Khārijite branches have a number of opinions that overlap on issues such as tawalla which means getting friends who think like them, tabarra which means staying away people from whom they do not regard as their selves, and sortie, belief, Imāmate which mean going for jihad for the people that they regard as ahl-Kufr etc.. It is possible to say that Ibāịīs are Khārijite sect by starting from this point of view that the meanings Ibādīs have imposed on these concepts are the meanings used by other Khārijite branches, the evaluations of the events those have come up from the period of four Caliphs, and the evaluations of the other Khārijite branches. Making tawalla by using a positive speech about Abū Bakr and 'Umar; Making tabarra by using a negative speech about Caliph 'Uthmān and Caliph 'Alì and declare both of them as unbelievers are the most obvious example of this situation. 


\section{Giriş}

Hicrî birinci yüzyılda neş'et eden ve adını kurucusu olan Abdullah b. İbâz'dan alan İ̉âziyye, Haricî fırkaların en mu'tedili olup günümüze ulaşan tek koludur. ${ }^{1}$ Klasik kelâm literatüründe Haricîliğin bir alt kolu olarak zikredilen İbazîlik, ${ }^{2}$ günümüz İbazîleri başta olmak üzere birçok araştırmacı tarafından ise Haricîliğin bir alt kolu olarak kabul görmemektedir. Öyle ki günümüz İbazîleri kendilerinin Haricî olarak takdim edilmesini kabul etmedikleri gibi bunu kendilerine yapılan bir hakaret ve zulüm olarak görürler. ${ }^{3}$

Haricîlik her ne kadar menşei itibariyle popüler bir oluşum olarak görülse de aydınlardan yoksun bir hareket olduğu söylenemez. Haricîliğin kültür ve edebiyata ilişkin birçok eseri, muhalifleri tarafından tahrif edilmiştir. Bunun sebebi de onların doğru yoldan uzaklaşmış olduklarına dair olan kanaatleridir. Yine neredeyse hayatlarının çoğunu savaş ve fiilî mücadelede geçirdikleri için kültürel miraslarının derlenip toplanmasının zorlaşmasına sebep olmuştur. Edebiyat alanında eserleri olduğu gibi diğer alanlarda da eserlerinin olma ihtimali yüksektir. ${ }^{4}$

Haricîliği iki dönem şeklinde tasnif etmek mümkündür. Haricîliğin ilk dönemi daha çok "Muhakkime" şeklinde nitelendirilebilir. Kur'an'a uyma çağrıları, ideal topluluk uğraşısı, kabile yaşantısı, gelenek ısrarı vb. özellikleri göze çarpmaktadır. Hicrî altmışlı yıllardan itibaren başlayan Haricîliğin ikinci döneminde ise Basra'da neş'et eden ilmî tartışmalar, entelektüel uğraşlar ve siyasî tutumları ilahiyat ile ilgili meselelerle özdeşleştirme teşebbüsleri dikkat çekicidir. ${ }^{5} \mathrm{Bu}$ yıllardan itibaren Haricîler arasında Ezârika, Sufriyye, Necedât ve araştırma konusu edindiğimiz İbâziyye gibi fırkalar neş'et etmiştir. Diğer fırkalar zamanla yok olurken İbâzîler günümüze kadar varlıklarını sürdürmüşlerdir. Zikredilen bu Hâricî fırkaların birbirine benzer görüşleri olduğu gibi farklı görüşleri de olmuştur. İbâzîler de diğer Haricî fırkaların birçok görüşüne benzer görüşlere sahip oldukları halde günümüze kadar gelen birçok İbâzî, kendilerinin Haricîlikle anılmasına sıcak bakmamaktadırlar. Biz de bu çalışmamızda Haricî fırkalar ve görüşleri hakkında

1 Ebû Rebî’ Süleyman el-Bârûnî, Muhtasar tarih-i İbâziyye, (y.y., Mektebetu'd-Dâmirî, 1995), 22; Ethem Ruhi Fığlalı, "İbâziye", Türkiye Diyanet Vakfı İslâm Ansiklopedisi (İstanbul: TDV Yayınları, 1999), 19: 256,258

2 Ebu'l-Hasan Ali b. İsmail el-Eş'arî, Makâlâtu'l-islâmiyyîn ve ihtilâfu'l-musallîn, Nşr. Naîm Zerzûr (Beyrût: Mektebetu'l-Asriyye, 2005), 1: 95-100; Abdulkâhir b. Tâhir el-Bağdâdî, el-Fark beyne'l-firak ve beyânu'l-firkati'n-nâciye minhum, Thk. Licnetu İhyâi't-Turâsi'l-Arabî fî̀ Dâri'l-Âfâki'l-Cedîd (Beyrût: Menşurâti'l-Dâri'l-Âfâki'l-Cedîd, 1982), 82-83; Ebu'l-Feth Muhammed b. Abdi'l-Kerîm Ebî Bekr Ahmed eş-Şehristânî, el-Milel ve'n-nihal, Thk. Emîr Ali Mehnâ- Ali Hasan Fâgûur (Beyrût: Dâru'l-Ma'rife, 1994), 156; İrfan Abdulhamid, Dırâsât fi'l-firaki'l-akâidi'l-islâmiyye, (Bağdat: Matbaatu'l-İsşâd 1967), 79.

3 Orhan Ateş, "İbaziyye Haricî Bir Fırka mıdır?", Avrasya Sosyal ve Ekonomi Araştırmaları Dergisi 17/1( Ocak 2017): 1-2; Harun Yıldız, "Ali Yahya Muammer' in Çalı̧̧malarında İbadilik", e-Makâlât Mezhep Araştırmaları, 8/1 (Bahar 2015) 21, 33-34,39-40. Bk. Ali Yahya Muammer, el-íbaziyye beyne'l-firaki'lislâmiyye inde küttâbi'l-makâlât fi'l-kadîm ve'l-hadîs, 2. Baskı, (b.y.: 1994), 1: 14-15, 51-52.

4 Azmi M. S. es-Salihi-Mustafa Öz, "Hariciler", Türkiye Diyanet Vakfı İslâm Ansiklopedisi (İstanbul: TDV Yayınları, 1997), 16: 175-176.

5 Harun Yıldız, “Haricî Düşüncenin Gelişimi”, OMÜifD, 11 (1999): 258-259, 264. 
bilgiler verip İbâzîlerin görüşlerini zikrederek bizzat onların görüş ve değerlendirmelerinden hareketle Haricî bir fırka olduklarını ortaya koymaya çalışacağız. Araştırmamızı İbâzî kelâmcıları Sâlim b. Zekvân'ın (I/VII yy), İbn Sellâm el-İbâzî (273/886), Ebû Abdillah el-Kalhâtî (IV/X yy), Vercelânî (471/1078), en-Nizvânî (h. VI. yy), Bârûnî ve diğer birçok İbâzî kelamcının eserlerinden ve görüşlerinden hareketle temellendirmeye çalışacağız. $\mathrm{Bu}$ çalışmamızda İbâziyye'nin görüşleriyle diğer Haricî fırkaların görüşlerini mukayese ederek deskriptif ve analitik bir yöntemle problemi izah etmeye çalışacağız.

\section{1. İbâziyye ve Diğer Haricî Fırkalar}

Hz. Ali dönemi ve sonrasında yaşanılanların neticesinde ana bünyede tutunamayacaklarını fark eden Haricîler, Afrika taraflarında Cezayir ve Uman'a gitmişlerdir ve orada Rüstemîler devletini oluşturmuşlardır. ${ }^{6}$ İlk İbâzî âlimlerden İbn Sellâm'a göre Hz. Osman'ın öldürülmesiyle fitnenin kapısı açılmış, Sıffîn'de hakeme başvurularak Allah'ın kitabına muhalefet edilmiş ve ümmet arasında iftirak oluşmuştur. Muaviye taraftarları bâtıla uymuşlardır ve ehl-i hakka gâlip gelmişlerdir. Müslümanlar da haktan korktuklarından dolayı Hanîf dini için savaşmışlardır. Yemen, Uman, Horasan, Trablus ve Mağrib civarlarındaki bu küçük topluluk aracılığıyla bu mücadele devam etmiştir. ${ }^{7}$ Eş'arî de Haricîlerin yaşadıkları yerleri zikrederken Cezire, Musul, Hadramevt, Mağrib ve Horasan'ın bazı bölgelerini saymaktadır. ${ }^{8}$ Çok güçlü deliller olmamakla birlikte İbâzîlerin Emevîler'de Mervân döneminde çok güçlü bir şekilde yayıldığı ifade edilmektedir. Ayrıca İbâzîlerin Umân, Horasan, Irak, Mısır'daki yayılışının Afrika'daki yayılışından daha önce olduğu ifade edilmektedir. ${ }^{9}$ Şunu da belirtelim ki Uman, günümüz İbâzîlerinin en fazla yaşadıkları önemli yerlerden birisidir. Bir de şunu da belirtelim ki günümüz İbâzîler'inin birçoğu kendilerine Mizâbî denilmesini tercih ederler. Mizâbiler, Cezayir ve Fas civarlarındaki Zenate kabilesinin Benî Musab kolundan olan Berberîlerdir. ${ }^{10}$ Mizâbîler, bulundukları yerlerde "Dâru'1Arş" müessesesiyle bir arada bulunmayı, ibadetlerini kendilerine tahsis ettikleri bu mekânlarda yapmayı ve birlikte hareket etmeyi sürdürmektedirler. ${ }^{11}$ Örneğin, Mizâbîler hakkında olumlu bir dil kullanan son dönem İbâzî müelliflerden Bârûnî’ye göre günümüz Tunus, Cezayir ve Libya civarlarında Cebel, Zuvvâre ve Cerbe tarafındaki birçok İbâzî, diğer mezheplerin mensupları gibi sıradan bir hayat yaşarlarken Mizâb ehli ve Umânlılar Kur'an ve Sünnet'e uygun bir şekilde yaşamaktadırlar. ${ }^{12}$

6 Mehmet Mahfuz Söylemez, "Mahfuzat: Cezayir İbâdîleri Arasında Beş Gün”, İslami İlimler Dergisi 10/1, (2015): 169-170.

İbn Sellâm el-İbâzî, Bedu'l-islâm ve şeraiu'd-dîn, Wiesbaden, Beyrut, 1986, 106-107.

Eş'arî, Makâlâtu'l-islâmiyyîn, 1: 112 .

Bârûnî, Muhtasar tarih-i ibâziyye, 31, 57.

10 İbrahim Bahhâz, "Mu'tezilî Mizâbîler", Çev. Adem Arıkan, İslâmî İlimler Dergisi 12/2 (Güz 2017): 180-182.

11 Söylemez, "Mahfuzat: Cezayir İbâdîleri Arasında Beş Gün”, 170.

12 Bârûnî, Muhtasar Tarih-i Ibâziyye, 30. 
Son dönem İbâzî müelliflerden Bârûnî, bazı kişilerin İbâziyye'yi hiç tanımadığını, bazılarının ise İbâziyye hakkında bir şeylerden haberdar olduğunu, ancak cehaletlerinden dolayı onları Ezârika, Necedât ve Sufriyye gibi Haricî gruplardan saydıklarını ifade etmektedir. Ona göre zikredilen bu gruplar zaten aşırılıklarından dolayı İslâm'dan çıkmışlardır. Çünkü bunlar muvahhitlerin mallarını gasp etmişler, kanlarını akıtmışlar, çocuk ve kadınlarını esir edinmişlerdir. Ama İbâzîler ise tüm bu gruplardan teberrî etmişlerdir, kesinlikle muvahhitlerin mallarına ve canlarına dokunmayı, çocuk ve kadınlarını esir edinmeyi haram addetmişlerdir. Bundan dolayı bu dalâlet ehli gruplar ile İslâm'ın en mu'tedili olan İbâzîleri birbirinden ayırt etmek gerekir.13 Seyyid'e İsmail Kâşif'e göre İbâzîlerin önemli âlimlerinden olan Kâlhâtî döneminde İbâzîler, kendileri için Haricîlik ismini kullanmakta sakınca görmezlerken, işin garip tarafı günümüz İbâzîleri Haricîlik ismiyle anılmaktan hoşlanmamakta ve ondan teberrî etmektedirler. Onlar, marjinal olan, yıkıcı davranışlar sergileyen Haricîler ile İbâzîlerin arasını ayırmak istiyorlar. Ayrıca Kalhâtî, İbâzî akidesini açıklamaya çalıştığını, İbâziyye'yi anlamayan, bazen İbâzilik ile zındıklığı birbirine karıştıran ya da gulat ile İbâzîleri birbirinden ayıramayan diğer fırka ve inanç gruplarına reddiyede bulunduğunu da ifade etmektedir. ${ }^{14}$

İbâzîler, kendilerini Haricîlerin ilk nüvesi olan "el-Muhakkimetü'1-Ûlâ"nın devamı olduklarını; ama "Ezârika"nın devamı olmadıklarını vurgulamaya çalışmaktadırlar. Bunu söylerken de Haricî olmadıklarını iddia etmektedirler. ${ }^{15}$ Örneğin ilk dönem İbâzî âlimlerinden Mezâtî (471/1079), diğer Haricîlerin gerekçelerini öne sürerek tahkîm olayına karşı çıkmakta ve Haricîler tarafından Hz. Ali'ye yapılanları tasvip etmektedir. ${ }^{16}$ Kalhâtî, Hz. Ali dönemi olaylarını resmederken Haricîlerin uygulamalarını müsbet bir dil ile aktarmaya çalışmaktadır. Ona göre Haricîler, Hz. Ali'yi hakeme başvurmaktan menetmeye çalışmışlardır. Ancak tüm uğraşların neticesinde bu karar uygulamaya konulduğunda onun yanında bulunan bir Müslüman grup "Lâ hükme illâ lillâh" diyerek onu terk etmişlerdir. Kalhâtî, bu terk etme durumunun doğru bir karar olduğunu onu terk edenlerin ise en hayırlı gruplardan olduklarını ifade etmektedir. ${ }^{17}$ Ona göre bu Müslüman grup daha sonra Harûra mevkiinde karar kılmışlardır. Onların dostları Kur'an, Sünnet ve ilk iki halifenin yolunu takip edenlerdir. Düşmanları ise Kur'an ve Sünnet'e isyan eden, ilk iki halifenin yolunu takip etmeyenlerdir. Kalhâtî, bu grubun Nâfi b. Ezrâk'a kadar hidayet üzerine yaşadıklarını, Nâfi'nin bu Müslüman grubun birliğini dağıttı̆̆ını, uygulamalarına muhalefet ettiğini, itikatlarından saptığını, yeni olayların vuku bulduğunu ve

13 Bârûnî, Muhtasar tarih-i ibâziyye, 2; Ebû Abdillah Muhammed b. Said el-Ezdî el-Kalhâtî, el-Keş̧ ve'lbeyân, Tahkik ve Şerh eden: Seyyide İsmail Kâşif, (y.y.: Metâbi' Sicili'l-Arab, 1980), 2: 423, 425.

14 Kâşif, "Mukaddime", el-Keşf ve'l-beyân, Tahkik ve Şerh eden: Seyyide İsmail Kâşif, (y.y.: Metâbi' Sicili'1-Arab, 1980), 1: 11-13.

15 Yıldız, Kendi Kaynakları Işı̆̆gnda Hâricîliğgin Doğuşu ve Gelişimi, 168; Ateş, “İbaziyye Haricî Bir Fırka midır?", 10.

16 Ebû Ali er-Rabî' b. Yahlef Mezâtî, et-Tuhefu'l-mahzune fi icmâi'l-usûli'ş-şer'iyye ve meânîhâ, Thk Mahmûd el-Endülüsî (y.y., b.y., 2009), 179-181.

17 Kalhâtî, el-Keşf ve'l-beyân, 2: 421. 
bununla Müslümanlara yani dinde istikamet ehli olanlara muhalefet ettiğini ifade etmektedir. ${ }^{18}$ Vercelânî (570/1175) ise Hz. Ali'yi tahkîmi kabul ettiği için küfürle itham etmiş ve Mü'minleri kasten öldürdüğü için cehennemlik olduğu iddiasında bulunmuştur. ${ }^{19}$ Ateş, her ne kadar İbaziyye'nin, kullandığ1 yöntem ve itikadî görüşleri açısından değerlendirildiğinde şiddet yöntemini kullanan ve kendilerinin dışındaki herkesi şirk anlamında tekfir eden Haricîler ile bir alakasının olmadığını iddia ediyorsa da ${ }^{20}$ onların Hz. Osman ve Hz. Ali'ye yönelik suçlamaları, Hz. Ali ile savaşan Haricîleri şehit olarak isimlendirmeleri vb. yaklaşımlarından hareketle Haricî şemsiye altında mütalaa edilmesinin daha makul olduğunu söylememiz mümkündür. İlk dönem Ehl-i Sünnet fırak edebiyatının da bu doğrultuda değerlendirilmesi mümkündür. Örneğin Eşarî, Haricîlerin Hz. Ali'yi tekfir etme hususunda icma ettiklerini, ama bu küfrün şirk küfrü olup olmadığı hususunda ise ihtilaf ettiklerini ifade etmektedir. Mesela İbâziyye'nin cumhuru, Muhakkime'yi dost edinmiş, Muhakkime'ye muhalif olan Ehl-i Salât'ın küfre girdiğini, ama müşrik olmadığını iddia etmiştir. ${ }^{21}$ İbazîler her ne kadar kendilerinin Haricîlikle anılmasını istemiyorlarsa da onların radikal olan Ezârika'dan farklı olduklarını ve daha ılımlı olan Sufriyye ve Necdîler gibi Haricî bir fırka olduklarını söylemek mümkündür. ${ }^{22}$ Örneğin ilk dönem İbâzî müelliflerden İbn Sellâm el-İbâzî'nin, Bedu'l-İslâm ve Şeraiu'd-Dîn ${ }^{23}$ adlı eserinde hakiki mü'min ile sözüyle mü'min olduğunu söyleyip de ameliyle onu tahrif eden kişi arasındaki ayırımı, onun Haricî mantaliteye sahip olduğunu göstermektedir. Bedu'l-İslâm ve Şeraiu'd-Dîn'in muhakkikleri de müellifin bu ayırımına dikkat çekmektedirler. ${ }^{24}$ İbn Sellâm, Haricîlerin ve Mu'tezile'nin mürtekib-i kebire, va'd ve va'îd ve tövbe hakkındaki görüşlerine benzer görüşleri savunmaktadır. Ona göre büyük günah işleyen tevbe ederse bağışlanır, tevbe etmezse Müslümanlar ondan teberrî eder ve bu hal üzere ölürse cehennem ona vacip olur. ${ }^{25}$ Yine imâmet ve halifeler hakkındaki değerlendirmesi de Haricî zihniyeti açıkça ortaya koymaktadır. Ona göre takip ettikleri din, Hz. Ebubekir ve Hz. Ömer'in, ensar ve mühacirden oluşan ashaptan

18 Kalhâtî, el-Keşf ve'l-beyân, 2: 422.

19 Ebû Ya'kub Yusuf İbrahim el-Vercelânî, ed-Delîl ve'l-burhân, Thk. eş-Şeyh Sâlim b. Hamdu'l-Hârisî (Maskat: Vizâretu't-Turâsi'1-Kavmî ve's-Sekâfe, 2006), 1: 41-42, 51.

20 Ateş, “İbaziyye Haricî Bir Fırka mıdır?”, 12.

21 Eş'arî, Makâlâtu'l-islâmiyyîn, 1: 84, 97.

22 Eş'arî, Makâlâtu'l-İslâmiyyîn, 1: 95; Yıldız, Kendi Kaynakları Işı̆ğında Hâricîliğgin Doğuşu ve Gelişimi, 168; Yıldız, "Haricî Düşüncenin Gelişimi", 265-266.

23 İbazîlerin tarihi ile ilgili olarak Şemmâhî'nin Kitâbu's-Siyer'inin ilk yazılan eser olduğu ifade ediliyordu. Ancak İbn Sellâm el-İbâzî'nin Bedu'l-İslâm ve Şeraiu'd-Dîn adlı eseri Şemmâhî'nin eserinden çok önce yazılmış ve Şemmâhî birçok konuda bu eserden istifade etmiştir. Bedu'l-İslâm günümüz İbâzîleri tarafından çok önemli bir eser olarak kabul görmektedir. Aynı şekilde Batı İslâm/Mağrib hakkında yazılmış en eski kitaplar arasında yer almaktadır. Arap ve Müslüman olmayanlara İslâm'ı anlatan en eski kitaplardandır. Bk. Werner Schvartz, eş-Şeyh Sâlim b. Ya'kub, "Mukaddime", Bedu'l-islâm ve şeraiu'd-dîn, (Beyrut: Wiesbaden, 1986), 5-7.

24 Werner Schvartz-eş-Şeyh Sâlim b. Ya'kub, "Mukaddime", 9.

25 İbn Sellâm el-İbâzî, Bedu'l-islâm ve şseraiu'd-dîn, 66-67, 94; Fığlalı, "İbâziyye", 259; Cemalettin Erdemci, İbn Sellam el-íbâdî ve İtikadi Görüşleri, (Yüksek Lisans Tezi, Yüzüncü Yıl Üniversitesi, 1996), 82-83. 
teşekkül eden topluluğun ve ümmetin ihtilaf ve iftirakından önce takip ettikleri dindir. ${ }^{26}$

Konumuzla bağlantısından dolayı burada değinmemiz gereken bir husus da İbâzîlerin din hakkındaki değerlendirmeleridir. Zira İbâzî müellifler, kendilerinin takip ettikleri dinin Allah'ın, Hz. Peygamber'in ve Müslümanların takip ettikleri din olduğunu ifade etmektedirler. Allah'ın dini, mükelleflerin kendi peygamberlerinin dilleriyle Allah'a ibadette bulundukları dindir. Allah katında dinin İslâm olduğu ve İslâm'ın da itaat anlamına geldiği vurgulanmaktadır. enNizvânî'ye göre din sadece itaat manasıyla sınırlandırılamaz ve itaati de aşan geniş bir manaya sahiptir. $\mathrm{O}$, dinde ulü'l-emre itaatin de olduğunu vurgulamaktadır. Ayrıca İslâm'ın ceza, hesap, âdet ve zât anlamlarına da geldiğini ifade etmektedir. ${ }^{27}$ Resulullah'ın dini ise Hz. Peygamber'in çağırdığı din olan Allah'ın dinidir ve Allah'ın dini ile Resulullah'ın dini arasında hiçbir fark yoktur. Müslümanların dininden kastettiği şey ise ilk iki halife Hz. Ebubekir ve Hz. Ömer'in, Nehrevân Ehli ile İbâzîlerin takip ettikleri dindir. Ona göre Nehrevân ehlinin dini, Hz. Peygamber'in, Hz. Ebubekir'in, Hz. Ömer'in ve Müslümanların takip ettikleri dindir. en-Nizvânî zikredilen bu dinlerin hiçbirisinin birbirinden farklı olmadığını, bilakis aynı din olduklarını ifade etmektedir. Ona göre Nehrevân ehline muhalif olan kişi ise cehennemliktir. Ayrıca Abdullah b. İbâz'dan sonra ortaya çıkan fırkalar hem din olarak hem de söz, fiil ve görüş olarak İbâzî dinine muhalif olarak ölmüştür. ${ }^{28}$ Burada dikkat çeken husus ise İbâzî müelliflerin mezhep kavramını kullanmayarak doğrudan din kavramını kullanmalarıdır. Onlara göre tek bir din vardır ve o da İbâzîlerin takip ettikleri dindir. Diğer mezheplerin takipçileri ise hak din üzerinde olmadıkları için cehennemliktirler. $\mathrm{Bu}$ ifadelerden hareketle bu şekil bir kullanımın ilk kez İbâzîler tarafından dile getirildiğini söyleyebiliriz.

Hz. Ali dönemi ve sonrasında yaşanılanların neticesinde ana bünyeden ayrılıp Afrika taraflarında Cezayir ve Uman'a giden Haricîler, karşı mihneden kaçan Mu'tezilîlere ev sahipliği yapmışlardır. Ef'alu'l-ibâd, sıfatlar meselesi gibi hususlarda tartıştıkları Mu'tezilîlerden etkilendikleri, önemli bir kısmını da kabul ettikleri ve tarih sahnesinden silinen Mu'tezile'nin bir kısım düşüncesini Zeydîler gibi sürdürdükleri ifade edilmektedir. ${ }^{29}$ Ama şunu da belirtelim ki ef'alu'l-ibâd meselesinde İbâzîlerin Eş'arîler gibi düşündükleri ve halk ve kesb nazariyesini benimsedikleri bizzat İbâzî olan Bârûnî tarafından ifade edilmektedir. ${ }^{30}$ Ayrıca Haricîlikte itikat alanında tam bir sistem kuran alt kolun, İbazîler olduğunu ve Haricîlerin İtikadî görüşlerinin zamanla liderlerinin ismiyle anılacak kollar

26 İbn Sellâm el-i̇bâzî, Bedu'l-islâm ve şeraiu'd-dîn, 70-73, 79. Erdemci, İbn Sellam el-İbâdî ve İtikadi Görüşleri, 86-89.

27 en-Nizvânî, el-Cevheru'l-muktasar, 128, 138.

28 en-Nizvânî, el-Cevheru'l-muktasar, 116, 132-136, 138-140, 142.

29 Söylemez, "Mahfuzat: Cezayir İbâdîleri Arasında Beş Gün”, 169-170.

30 Bârûnî, Muhtasar tarih-i ibâziyye, 2-3. Eş'arîlerin kesb nazariyesi hakkındaki görüşleri için bk. Mehmet Keskin, İmam Eş'arî ve Eş'arilik, (İstanbul: Düşün Yayıncllı, 2013), 262-270; Uysal, "Ehl-i Sünnet ve Mu'tezile'ye Göre Kesb Nazariyesi", 42-45. 
aracılığıyla aktarıldığını söylemek mümkündür. ${ }^{31}$ Haricî ileri gelenler daha çok makale türü eserler yazmışlardır ve çoğu da günümüze kadar gelmemiştir. ${ }^{32}$ Ilımlı Haricîler olan İbâzîler'in tevhid meselesi hakkındaki görüşleri Mu'tezilenin görüşleri gibidir. Onlar Basra'da baskın düşünce olan Mu'tezilî düşünceden etkilenmişlerdir. Anti-antropomorfist teolojileri, Mu'tezile kelâmından bağımsız değildir. ${ }^{33}$ Örneğin rü'yetullah meselesinde Mu'tezile'nin yaptığı gibi ayetlerden hareketle bunun imkânsiz olduğunu savunurlar. Onlara göre de Allah Teâlâ cisimlere benzemez. Çünkü gözle görülen her şey hâdis varlıklara benzeyeceğinden dolayı Allah Teâlâ gözle görülemez. Zira görmede yer ve yön tayini vardır. Allah Teâlâ ise bundan münezzehtir. ${ }^{34}$ Yüce Allah hakkında teşbihten uzak, tenzihi bir dili savunmuşlardır. ${ }^{35}$ Tevhîd meselesinde Haricîlerin Mu'tezile ile aynı görüşleri benimsediklerini söyleyen Eş'arî’ye göre Haricîlerin tümü Halku'l-Kur'an görüşünü benimsemişlerdir; ama İbâzîler, Mu'tezile'ye sadece tevhid ile ilgili olan meselelerden biri olan irade konusunda muhalefet etmişlerdir. ${ }^{36}$ Örneğin, İbâzî kelâmcı Vercelânî, Eş'arîlerin Kur'an'ın mahlûk olmadığıyla ilgili görüşlerini eleştirerek Halku'l-Kur'an görüşünü savunmuştur. ${ }^{37}$ Buna rağmen son dönem İbâzî âlimlerinden Bârûnî, İbâzîlerin Mu'tezile'den sayılmasını gerçek dışı bir durum olduğunu söylemektedir. Ona göre Mu'tezile ile İbâziyye iki farklı akımdır. Örneğin, kaza-kader ve insan fiillerinin yaratılışı hakkında farklı görüşlere sahiptir. Bârûnî, İbâzîlerin bu konularda Eş'ariler gibi düşündüklerini ifade etmektedir. Ona göre İbâzîler bu hususta ne Mücbire gibi düşünmektedirler ne de insanların fiillerinin yaratıcısı oldukların söylemektedirler. Onlar da Eş'arîler gibi halk ve kesb görüşünü savunmaktadırlar. ${ }^{38}$ Eş'arî de kader meselesinde Harisiyye hariç diğer İbâzî fırkaların Mu'tezile'den farklı düşündüklerini ve bu konuda Harisiyye'ye muhalefet ettiklerini ifade etmektedir. Ona göre İbâzîlerin çoğu kulların fiillerinin mahlûk olduğunu savunmuşlardır. ${ }^{39}$ Hicrî 1059-1079 yılları arasında yazılan ve doksan cilt olduğu söylenilen İbâzîlerin önemli eserleri arasında yer alan Kâmusu'şŞer'ia'da bu konu ayrıntılı bir şekilde tartışılmıştır. Müellif, fiillerin hareket ve sükûn olmak üzere iki yönde olduğunu ve Allah tarafından halk edildiğini, insanlar tarafından ise kesbedildiğini ifade etmektedir. Mu'tezile'nin kulların kendi fiillerinin yaratıcısı olduğunu savunduğunu, ama ızdırarî fiiller hususunda ise farklı görüşleri öne sürdüğünü, buna karşlık Mücbire ve Cehmiyye'nin ise

31 Ethem Ruhi Fığlalı, "Hariciler", Türkiye Diyanet Vakfı İslâm Ansiklopedisi (İstanbul: TDV Yayınları, 1997), 16: 172.

32 Fığlalı, "Hariciler", 174; Wilferd Madelung, "Eş'arî Öncesi Kelâma Şî̂ ve Haricî Katkı", trc. Süleyman Akkuş, Sakarya Üniversitesi İlahiyat Fakültesi Dergisi 15 (2007): 175-177.

33 Eş'arî, Makâlâtu'l-islâmiyyîn, I: 108-109; Madelung, "Eş'arî Öncesi Kelâma Şiî ve Haricî Katk1", 179; Yıldız, "Haricî Düşüncenin Gelişimi", 268-269.

34 Vercelânî, ed-Delîl ve'l-burhân, I: 59; Bârûnî, Muhtasar tarih-i ibâziyye, 73; Ethem Ruhi Fiğlalı “İbâdiye'nin Siyasî ve İtikadî Görüşleri”, Ankara Üniversitesi İlahiyat Fakültesi Dergisi 21, (1976), 342.

35 Ali Yahya Muammer, el-íbâziyye mezhebun islâmiyyun mu'tedilun, 2. Baskı (y.y.: Vizâretu'l-Evkâf ve'ş-Şuûni'd-Diniyye Mektebetu'l-İfta', 1979) 27-28, 54

36 Eş'arî, Makâlâtu'l-islâmiyyîn, 1: 99, 108-109.

37 Vercelânî, ed-Delîl ve'l-burhân, 1: 59, 72-73.

38 Bârûnî, Muhtasar tarih-i İbâziyye, 2-3. Krş. Keskin, İmam Eş'arî ve Eş'arilik, 262-270.

39 Eş'arî, Makâlâtu'l-islâmiyyîn, 1: 97, 99. 
fiilleri Allah'a izafe ettiklerini aktardıktan sonra ümmetin geri kalan kısmının ise ihtilaflarıyla birlikte halk ve kesb görüşünü savunduklarını ifade etmektedir. ${ }^{40}$

İbâzî âlimler, Hz. Ali dönemi olayları neticesinde neşet eden Haricîlerden olumlu bir dil ile bahsederlerken, bu söylemlerini Nâfi b. Ezrâk'tan bahsettikleri andan itibaren o ve ona tabi olanlar hakkında değiştirerek eleştirel bir dile dönüştürürler. Kalhâtî'ye göre Haricîler Nâfi b. Ezrâk'tan sonra peşi sıra ortaya çıkmışlardır ve Ehl-i İstikâmet fırkasından on altı fırkaya ayrılmışlardır. O, ilk sırada Abdullah b. Vehb er-Râsibî'ye nisbetle Vehbiyye'ye yer vermekte ve onların Haricî fırkalar içerisinde İbâziyye ile birlikte istikamet ehli olan iki fırka olduğunu ifade etmektedir. ${ }^{41}$ Nâfi b. Ezrâk'ın istikamet ehlinin inancına muhalefet eden ilk kişi olduğunu belirterek yanlışlıklarını teker teker zikretmektedir. Ona göre Nâfi b. Ezrâk, Müslümanların birlikteliğini bozmuş, cemaatlerini dağıtmış, kıble ehlini şirkle itham etmeyi alışkanlık edinmiş, kendi mezheplerine tabi olduklarını bildiği halde Kaade' den $^{42}$ teberrî etmiş, Mekke fethinden sonra hicretin olmayacağ sadece cihadın olabileceği hadislerine rağmen hicret ismini sahiplenmeye çalışmıştır. ${ }^{43}$ Eş'arî de Haricîler'de ilk ihtilafı oluşturan kişinin Nâf'i' b. Ezrâk olduğunu söyleyerek buna örnek olarak da onun kaadeyi ve kendileriyle birlikte hicrete çıkmayanları tekfir etmesini vermektedir. ${ }^{44}$ Kalhâtî'ye göre İbn Ezrâk, hicret hakkında yanıldığı gibi isti'raz ${ }^{45}$ meselesinde de yanlış düşünmüştür. Zira yüce Allah kıble ehline müşriklerin hükümlerinden farklı bir şekilde hükmetmiştir. Çünkü Allah Teâlâ bağiler için esir almak ve mallarına el koymakla hükmetmemiştir. Müslümanlar Osman b. Affân'ı öldürürken onun kanından başka bir şeyi helal kılmamışlardır, çoluk-çocuğunu esir edinmemişler ve mallarını da gasp etmemişlerdir. Öyle ki Osman b. Affân'ın öldürülmesinden sonra Müslümanlar yaklaşık olarak otuz yıl boyunca bazı günahlar hariç birliktelik içinde yaşamışlar, birbirlerini ötekileştirmeden evlilik, miras, alışveriş hukukuna riayet etmişler. Ama Allah Teâlâ onları dalâlete sürükleyip gözlerini kör ettikten

40 Cumeyyil b. Hamîs b. Lâfî b. Hilfan b. Hamîs es-Sa'dî, Kamusu'ş-şeri'a el-hâvî turukuhe'l-vesî'ah, (Umân: Vizâretu't-Turâsi'l-Kavmî ve's-Sekâfe, 1983), 5: 54, 61, 113-114. Hicrî 1059-1079 yılları arasında yazılan ve doksan cilt olduğu söylenilen bu eserin Zengibar'da 1880'den itibaren sadece on cildi basılmıştır. Bu eserde İbâziyye'nin tarihi, imamları, kelâm ve fıkıh hakkında birçok bilgi mevcuttur. Bk. Kutluay, "İbâdîlere Ait Bazı Metinler", 401-402.

41 Kalhâtî, el-Keşf ve'l-beyân, 2: 422-423.

42 Kaade, Haricîlerin aşırıya kaçan kolu olan Ezârika'nın, Haricî olduğu halde kendi fırka mensuplarının, muhalifleriyle savaşmak için toplandıkları yere gitmeyip onlara fiilen destek vermeyen ve savaşlarda geri kalan kimseler için kullandıkları bir kavramdır. Bkz. Mustafa Öz, “Kaade”, Türkiye Diyanet Vakfı İslâm Ansiklopedisi (İstanbul: TDV Yayınları, 2001), 23: 589.

43 Kalhâtî, el-Keş̧ ve'l-beyân, 2: 423,425.

44 Eş'arî, Makâlâtu'l-islâmiyyîn, 1: 84.

45 İsti'raz, Haricîliğin bir kolu olan Ezârika'nın ortaya çıkışından itibaren kişini inanç ve kanaatini açıklamasını istemek ve hiç çekinmeden adam öldürmek anlamında kullanılmıştır. Ezârika kendilerine katılmak isteyenlerin samimiyetlerini test etmek için yanlarında bulundurdukları esirleri öldürmelerini talep ederler. Eğer esiri öldürürlerse samimiyetlerini ortaya koymuş olurlar. Eğer öldürmezlerse o zaman münafık ve müşrik addedilirler ve kendileri öldürülürler. Ne var ki Hristiyan ve Yahudi gibi gayr-1 Müslimler için isti'razın uygulanmasını haram saymışlardır. Bkz. Mustafa Öz, "İsti'raz", Türkiye Diyanet Vakfı İslâm Ansiklopedisi (İstanbul: TDV Yayınları, 2001), 23: 374. 
sonra kıble ehlini şirk ehli mesabesine düşürmüştür. ${ }^{46}$ Yine diğer bir İbâzî kelâmcı olan en-Nizvânî de Haricîlerin, hicret meselesinde kendilerine muhalif olan kıble ehlinin şirk ile hükmettiklerini ve böyle bir düşüncenin çok tuhaf bir şey olduğunu ifade etmektedir. ${ }^{47}$ Kalhâtî'ye göre Ezârika kendilerinden olmayanları Daru'ş-Şirk ile itham ederlerken kendilerinden olup da Allah'ın haram kıldığ 1 fiilleri işleyen ve hatta bu hal üzere ölenleri bile cennetlik olduklarına hükmetmişlerdir. ${ }^{48}$ Kalhâtî daha sonra Necedât ve diğer Haricî fırkaları ve yanlışlıklarını teker teker zikrettikten sonra Ehl-i İstikâmet dedikleri İbâziyye'den bahsetmektedir. ${ }^{49}$

İbâzîlerin Haricîlik lafzından kastettikleri şey, bizzat Ezârika'dır. Zira İbâzîlerin önemli kelâmcıları arasında yer alan en-Nizvânî'ye göre Ezârika, Mârika ve Haricîlik aynı anlama gelmektedir. en-Nizvânî'ye göre bunlar kıble ehlinden olup da kendilerine muhalif olan herkesi şirk ile itham etmişler, kanlarını helal kılmışlar, çoluk çocuklarını esir almayı, mallarını gasp etmeyi mübah görmüşlerdir. ${ }^{50}$ Buna benzer ifadeleri diğer bir İbâzî kelâmcı olan Vercelânî'nin de kullandığı görülmektedir. Vercelânî'nin Mârika eleştirisi, onların küçük ya da büyük günah işleyen herkesin Allah Teâlâ'ya şirk koştukları şeklindeki görüşlerine yönelik olmuştur. Ona göre Mârikâ, Allah Teâlâ'nın "Üzerine Allah adı anılmayan (hayvan)lardan yemeyin. Çünkü bu şekilde davranış fâsıklıktır. Bir de şeytanlar kendi dostlarına sizinle mücadele etmeleri için mutlaka fisıldarlar. Onlara boyun eğerseniz şüphesiz siz de Allah'a şirk koşmuşolursunuz" (el-En'am 6/121) ayetini yanlış te'vil ederek Allah'a isyan eden herkese müşrik ismini yapıştırmışlardır. Bunun neticesinde ise onların erkeklerini öldürmeyi, kadın ve çocuklarını esir edinmeyi ve mallarını gasp etmeyi helâl görmüşlerdir. ${ }^{51}$ Mârikâ'nın günahkâr ve cehennemlik olduğunu söyleyen en-Nizvânî'ye göre bunlara reddiyede bulunmaya bile gerek yoktur. Bunlardan birçok grup vardır ve kendilerinden teberrî edilmesi gerekir. Zaten Abdullah b. İbâz da bunlara karşı çıkmıştır. ${ }^{52}$ Ancak bu konuda dikkat çeken bir husus vardır. O da en-Nizvânî'nin, Abdullah b. İbâz'ın bu fırka hakkındaki yaklaşımını kabul etmemesidir. Ona göre Abdullah b. İbâz, Ezârika'nın bu tutumunu hata ve dalâlet olarak değerlendirmesine karşılık, kendilerinin bu fırkanın inancı üzerine ölen herkesin cehennemlik olduğuna şahitlikte bulunduklarını vurgulamaktadır. ${ }^{53}$ Yeri gelmişken şunu da belirtelim ki birçok fırak müellifinin eserlerini tasnif ederlerken kendilerini etkileyen iftirak hadisi, İbâzî kelâmcıları da etkilemiştir. İbâzî kelâmcılar da iftirak hadisini zikrederek İbâzîlerin dışındaki diğer ekollerin Fırak-1 Dâlle ve cehennemlik olduklarına hükmetmektedirler. Onlara göre Mu'tezile, Mücbire, Mürcie, Haricîler, Rafızîler ve diğer fırkalar İbâziyye'nin görüşlerini benimsemedikleri için

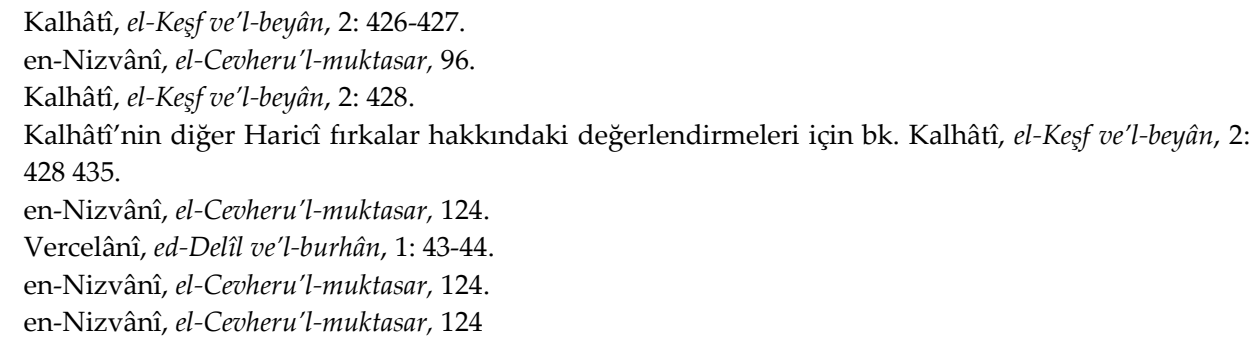


cehennemliktirler. Mü'minlerin bunlardan teberrrî ettikleri gibi kendilerinin de bunlardan teberrî ettiklerini ifade etmektedirler. Öyle ki en-Nizvânî çok kesin ifadelerle bu mezheplere bağlı olarak ölenlerin Allah Teâlâ'nin kâfirlere va'idde bulunduğu cehennem ehli olduklarına şahitlikte bulunduklarını ifade etmektedir. ${ }^{54}$ En yüce derecenin Kitap ve Sünnet'e tutunan Ehl-i Hakk'in derecesi olduğu ve bunların da şirk ve küfür ehlini terk eden ve faziletli olan İbâzîlerin en hayırlıları olduğu iddia edilmektedir. Öyle ki bu kişiler, dalâlet ve ifk ehlinden ayrılmaktadırlar ve Mürcie ve mürtekib-i kebirenin şefaatle cennete gideceğini iddia eden Şukkâk'tan teberrî etmektedirler. Aynı şekilde Şurât, Muhakkime ve velâyet ehli olduklarını, bağışlanmayı hak edenler olduklarını ve Allah'ın nimetlendirmiş olduğu nebi, sıddık ve şehitlerle beraber olduklarını ifade etmektedirler. ${ }^{55}$ en-Nizvânî'ye göre kendilerini Sünnet ve Cemaat ehli olarak isimlendiren Haşeviyye, ma'siyet ehlinin halis mü'min olduğu ve cennetlik olduğu görüşündedir. Ne var ki Müslümanlar, onların bu konuda yalan söylediklerini ve Ehl-i Sünnet ve'l-Cemaat olmadıklarını, bilakis Ehl-i Bid'at ve'l-Fırka olduklarını söylemişlerdir. ${ }^{56}$ en-Nizvân'nın Ehl-i Sünnet ve'l-Cemaat tabiri yerine Ehl-i Bid'at ve'l-Fırka tabirini kullanması dikkat çekicidir. Zira ona göre Haşeviyye bu görüşüyle "Ehl-i Sünnet” kapsamından çıkarak Ehl-i Bid'at olmuştur ve birliktelik anlamına gelen "cemaat" anlamından çıkıp fırka ehli olmuştur. en-Nizvânî, fırka lafzına menfî bir anlam yükleyerek onu cemaat kavramının karşıtı bir anlamda kullanmıştır.

Yukarıdaki ifadelerde görüldüğü gibi İbâzîler, kendilerinden olmadıklarını iddia ettikleri diğer İslâmî fırkaların hepsinin küfür ehli olduklarını ve sonsuza değin cehennemde kalacaklarını söyleyerek Haricî söylemi savunmaktadırlar.

\section{2. İbâzîlerin Haricîliği Meselesi}

Her ne kadar birçok İbâzî, kendilerinin Haricî ismiyle anılmasına karşı çıkmış olsalar da biz ilk dönem İbâzî âlimlerden itibaren İbâzî literatüründen hareketle onların görüşleriyle Haricîlerin görüşlerini mukayese ederek onların Haricîlerin mu'tedil bir fırkası olduğunu ortaya koymaya çalışacağız. Bunun için de ilk önce İbâzîlerin ilk âlimlerinden olan Sâlim b. Zekvân'ın (I/VII yy) görüşlerini aktaracağız ve daha sonra ondan etkilenmiş olan İbâzî âlimlerden ${ }^{57}$ İbn Sellâm elİbâzî (273/886), Ebû Abdillah el-Kalhâtî (IV/X yy), Vercelânî (471/1078), en-Nizvânî (h. VI. yy) vb. âlimler ile günümüz bazı İbâzî müelliflerin görüşlerinden hareketle İbâzîlerin Haricîliği meselesini temellendirmeye çalışacağız.

Sâlim b. Zekvân ve es-Sîre adlı eseri Haricî ve İbâzî tarihi içinde önemli bir yere sahiptir. es-Sîre'nin hicrî yetmiş̧li yılların başında yazılmış olması kuvvetle muhtemeldir. Çünkü Haricîlerin Ezârika, Necedât gibi alt kollarına yer vermiş,

54 Kalhâtî, el-Keş̧f ve'l-beyân, 2: 323 vd; en-Nizvânî, el-Cevheru'l-muktasar, 121-125; Vercelânî, ed-Delîl ve'l-burhân, 2: 64-67.

55 en-Nizvânî, el-Cevheru'l-muktasar, 126, 138.

56 en-Nizvânî, el-Cevheru'l-muktasar, 141.

57 Sâlim b. Zekvân'dan etkilenmiş olan İbâzî âlimler için bk. Yıldız, "Sâlim b. Zekvân ve es-Sîre Adlı Eseri", 29. 
ama Haricîlerin yetmişli yıllarından sonraki olaylarına yer vermemiştir. ${ }^{58}$ Sâlim b. Zekvân kendisi gibi düşünenleri "Haricîler" olarak isimlendirmiyor, kendilerini mu'tedil olarak tanımladığı Kaade'nin takipçileri olarak değerlendiriyor ve kendileri ile aşırı Haricî grupların arasını ayırmaya çalışıyor. ${ }^{59}$ Ama Hz. Osman ve Hz. Ali dönemindeki olayları yorumlama biçimi bize Haricîlerin ve İbâzîlerin bakış açısını göstermektedir. ${ }^{60} \mathrm{~Hz}$. Ebubekir'i adaletli ve dürüst birisi olarak niteleyerek seçimle başa gelen hak bir halife olduğunu belirtiyor. Hz. Ömer'i de aynı şekilde överek onun ölünceye kadar Hz. Ebubekir ve Hz. Peygamber'in yolunu takip ettiğini ifade ediyor. ${ }^{61} \mathrm{~Hz}$. Osman'ın da Müslümanların istişaresi ve rızasıyla halife seçildiğini, belli bir süre Kitap ve Sünnet'e uyduğunu, daha sonra dünyaya meylettiğini, Sünneti değiştirerek bidatleri ihdas ettiğini zikrediyor. Öyle ki bazı örnekleri teker teker zikrettikten sonra Maide 44. ayetini delil getirmek suretiyle Allah'ın hükmünün çiğnendiğini ve O'nun hükmünün dişında başka bir hükümle hükmettiğini söylüyor. Sâlim b. Zekvân bu konu hakkındaki görüşlerini desteklemek için örnekler veriyor. Abdullah b. Erkâm'ın beytü'l-maldan sorumlu olduğunu, Hz. Osman'ın beytü’l-maldan aldığı malı gasp ettiğini ve bunu vermeyi red ettiği için de Abdullah b. Erkâm'ı görevinden azlettiğini ifade ediyor. Yine Ebû Mûsâ el-Eş'arî'nin onun beytü'l-maldaki varlığı ailesine dağıttığına şahit olduğunu ve bu yanlışını kendisine bildirmesine rağmen onun bundan vaz geçmediğini bildiriyor. Sâlim b. Zekvân, Hz. Osman'ın Velid b. Ukbe'ye kısas uygulamayarak ve içki cezasını vermeyerek Allah'ın ayetini çiğnediğini, fâsıklardan olduğunu, Maide 47. ayeti de zikrederek ifade ediyor. ${ }^{62}$ Yine bedevilerin gayr-1 menkullerini gasp ederek zimmetine geçirdiğini, savaş gelirleri eksilir kaygısıyla onları cihattan menettiğini ve bu davranışıyla Hz. Peygamber, Ebubekir ve Ömer'in uygulamalarından uzaklaşarak Sünnet'e muhalif davrandığını ve doğru olmayan bir yolu tercih ettiğini zikrediyor. İbn Zekvân, Hz. Osman hakkında bu tür söylemleri aktardıktan sonra Nisa 115. ayetini de zikrederek onun cehennemlik olduğunu iddia etmektedir. Sâlim b. Zekvân Hz. Osman'ın zikredilen bütün bu haksız uygulamalarına karşı çıkan ve kendisine nasihatte bulunan ashaba karşı kaba ve sert davrandığını, onlardan bazılarını sürgüne yolladığını ifade ettikten sonra Bakara 84-86. ayetlerinin muhatabının âdeta Hz. Osman olduğunu söylüyor. ${ }^{63}$

İbn Zekvân'ın Hz. Osman hakkındaki bu değerlendirmelerinin nerdeyse aynısını daha sonraki İbâzî bilginlerde de görmek mümkündür. İbâzîlerin genel yaklaşımında olduğu gibi ilk iki halifeyi tevellâ eden Vercelânî de İbn Zekvân'ın Hz. Osman hakkındaki değerlendirmelerinin benzerini zikrederek, onun azlinin ve

\footnotetext{
Yıldız, "Sâlim b. Zekvân ve es-Sîre Adlı Eseri”, 15, 22-24.

Yıldız, "Sâlim b. Zekvân ve es-Sîre Adlı Eseri", 29.

Yıldız, "Sâlim b. Zekvân ve es-Sîre Adlı Eseri", 29.

Sâlim b. Zekvân, es-Sîre Bir Hâricîlilbâdî Klasĭği, trc. Harun Yıldız, (Ankara: Ankara Okulu Yayınları, 2016), 56-58.

62 İbn Zekvân, es-Sîre, 58-60.

63 İbn Zekvân, es-Sîre, 61-62.
} 
öldürülmesinin hak olduğunu ifade etmektedir.64 İbn Zekvân, Hz. Osman'ın Mü'minlerin tüm girişimlerine rağmen dalâletinden vaz geçmediği için öldürüldüğünü; ama Müslüman topluluğun onun geride bırakmış olduğu şeylere dokunmadıklarını, Hz. Peygamber'in kıble ehlinden öldürülenlere uyguladığı hükmü uyguladıklarını, çocuklarını esir almadıklarını, mallarını yağmalamadıklarını ve mallarının beşte birini almadıklarını, onları mirastan mahrum etmediklerini ve iddet süreleri bitinceye kadar kadınlarıyla nikâhlanmadıklarını aktarmaktadır. ${ }^{65}$

Sâlim b. Zekvân'dan aktardığımız bu anekdotlar Haricîlerin de savundukları ve öne sürdükleri iddialardır. Âdeta Haricîlerin Hz. Ali'yi sorguya çektikleri gibi bu "Mü'min" grubun da Hz. Osman'ı sorguya çektiklerinin resmini çizmektedir. Ancak şunu da belirtelim ki İbn Zekvân, bu topluluğun Hz. Osman'1 öldürmelerinden sonra ailesine ve geride bıraktıklarına yönelik yaptıkları uygulamaların kıble ehline yapılan uygulamalar olduğuna dikkat çekmektedir. Büyük bir ihtimalle burada kâfirlere uygulanan hükümlerin Hz. Osman'a uygulanmadığını zikretmekle radikal Haricî mantalitesinden daha ılımlı bir yaklaşımın resmini sunmaya çalışmaktadır. Durum her ne olursa olsun Hz. Osman hakkındaki uygulamalar ve düşünce yapısını değerlendirme biçimi Haricî zihniyetten pek de farklı değildir.

İbn Zekvân, Talha ve Zübeyr'in Hz. Osman döneminde ondan hoşnut olmamalarına rağmen Hz. Ali'nin onun kanını alması gerektiği bahanesiyle ona karşı çıktıklarını ve onların Müslümanların düşmanları olduklarını, taşkınlıklarından dolayı da sayılamayacak kadar çok kişiyle beraber öldürüldüklerini ve Hz. Osman'a uygulanan kıble ehlinden kötülük yapanlara yapılan uygulamaların kendilerine de uygulandığını zikreder. ${ }^{66}$ Daha sonra Hz. Ali'nin Sıffîn'de Müslümanların yolundan yüz çevirdiğini, Allah'ın hüküm verdiği bir işte, Allah'ın dışında başka birisini hakem tayin ederek Mü'min 20. ve Tin 8 . ayetlerinin muhatabı ve Allah'ın düşmanı olduğunu, bundan vazgeçip fitne ortadan kalkıncaya kadar kendisiyle savaşılması gerektiğini ifade ediyor. ${ }^{67}$ Şunu da belirtelim ki Haricîliğin temel referanslarında olduğu gibi Sâlim b. Zekvân da Hz. Ali'yi tahkîm öncesi ve sonrası olmak üzere farklı bir şekilde tasvir etmeye çalışır. Hz. Ali'nin hakemi kabul ederek Allah'a ve oradaki Müslümanlara düşman olduğunu ve oradaki Müslümanların da Hz. Ali'nin Allah'ın ve kendilerinin düşmanı ve kâfir olduğuna şahitlik ettiklerini ve onunla yollarını ayırdıklarını, Allah'ın rızasını umarak canların feda ettiklerini ifade ediyor. ${ }^{68}$ Buna benzer

64 Vercelânî, ed-Delîl ve'l-burhân, 1: 39-41. İmâmet meselesinde Ehl-i Sünnet ve Şia'dan farklı bir yaklaşım sergileyen Haricîler ilk iki halifeyi âdil, Hz. Osman'ın ikinci altı yılını ve Hz. Ali'nin tahkîmden sonraki yaşantısını bâtıl olarak değerlendirmektedirler. Aynı yaklaşımı İbâzî metinlerden de görmek mümkündür. Bk. Eş'arî, Makâlâtu'l-islâmiyyîn, 1: 109-110; Vercelânî, ed-Delîl ve'l-burhân, 1: 39-42; Yaşar Kutluay, "İbâdîlere Ait Bazı Metinler", AüİFD, 15 (1967): 141-144; Fığlalı, "İbâziyye", 258-259

65 İbn Zekvân, es-Sîre, 63-65.

66 İbn Zekvân, es-Sîre, 65-66.

67 İbn Zekvân, es-Sîre, 66-67.

68 İbn Zekvân, es-Sîre, 68. 
ifadeler daha sonraki İbâzî kelâmcılar tarafından da dile getirilmiştir. Örneğin, Hz. Ali'nin hak bir şekilde halife seçildiğini, Cemel'deki uygulamalarının iyi olduğunu zikreden Vercelânî, Hz. Ali hakkında tahkîm sonrası için olumsuz bir dil kullanır ve onun Mü'minleri kasten öldürdüğü için cehennemlik olduğunu ifade eder. ${ }^{69}$ Günümüz İbâzî müelliflerinden Bârûnî'ye göre Sıffîn Savaşında hakem önerisiyle Ali b. Ebî Tâlib şaşırıp kalmıştır. Öyle ki bu öneri karşısında iki tutum sergilenmiştir. Abdullah b. Vehb er-Râsibî'nin başını çektiği grup, bunun bir hile olduğunu, buna fırsat verilmemesini ve zafer elde edilinceye kadar savaşılması gerektiğini söylemiştir. Diğer grup ise Müslüman kanının akıtılmaması için müzakerelerin daha iyi olacağını söylemiştir. Bu görüş baskın gelmiş ve ma'lum süreç gerçekleşmiştir. ${ }^{70}$

İbâzîler tahkîm olayındaki Haricîler hakkında çok olumlu bir portre çizmeye çalışmaktadırlar. Onların, rakiplerinin çoluk çocuklarına karışmadıklarını, mal ve namuslarını kendilerine helal kılmadıklarını, isti'raza başvurmadıklarını, mirastan kimseyi men etmediklerini, adaletle hükmettiklerini, herkesin kendilerini onların yanında güvende hissettiklerini, akrabalık ilişkilerini gözetlediklerini, her hak sahibine haklarını teslim ettiklerini aktarmaktadırlar. ${ }^{71}$ İbâzîlerin Haricî bir fırka olduğunu söyleyen Eş'arî de onların Ezârika gibi diğer radikal Haricî fırkalardan ayrıldıkları görüşlerden birisinin de isti'razı haram görmeleri olduğunu ifade etmektedir. ${ }^{72}$ Yine dikkat çekilmesi gereken bir husus da şudur: İbâzîler, savaşa çıanların Kaade'yi sevip onlara dost olduklarını ve Kaade' nin de savaşanlara aynı hissiyatla yaklaştıklarını vurgulamaktadırlar. Belki de İbâzîler ile Haricîlerin diğer bir kolu olan Ezârika arasındaki en önemli farklardan birisi İsti'raza yaklaşım tarzlarıdır. Örneğin, Sâlim b. Zekvân'ın bizzat "Müslümanların Haricîleri" ifadesini kullandıktan sonra onların isti'raz yapmadıklarını vurgulaması, Ezârika'dan farklı olduklarını belirtmek içindir. Gerçi tahkîm olayı sürecinde isti'raz, Haricîlerin kendilerine yeni katılan kişileri deneyerek, duygu ve düşüncelerini ortaya koymak için başvurdukları bir uygulama şekliydi. Ancak Ezârika ile birlikte farklı bir uygulamaya evrildiği ve muhalif fırkalara karşı çok sert bir şekilde uygulandığı ifade edilmektedir. ${ }^{73}$

Hz. Ali dönemi olayları neticesinde ortaya çıkan ilk Haricîlerden sonra İbnu'lEzrâk ve taraftarları ortaya çıkmıştır. Ezârika'nın "Müslümanların Haricîleri"nden sonra ortaya çıktığını söyleyen İbn Zekvân, onların kendilerinden önceki Haricîlerin yolunu takip ederek Allah'ın takdir ettiği kadar yaşadıklarını zikretmiştir. ${ }^{74}$ İbn Zekvân, Ezârika'nın zamanla kendi kavimlerine besledikleri kin neticesinde onları müşrik konumunda görmeye başladıkları ve onlarla kendi aralarındaki miras bağını kestiklerini belirtiyor. Öyle ki Ezârika'nın sevmiş olduğu

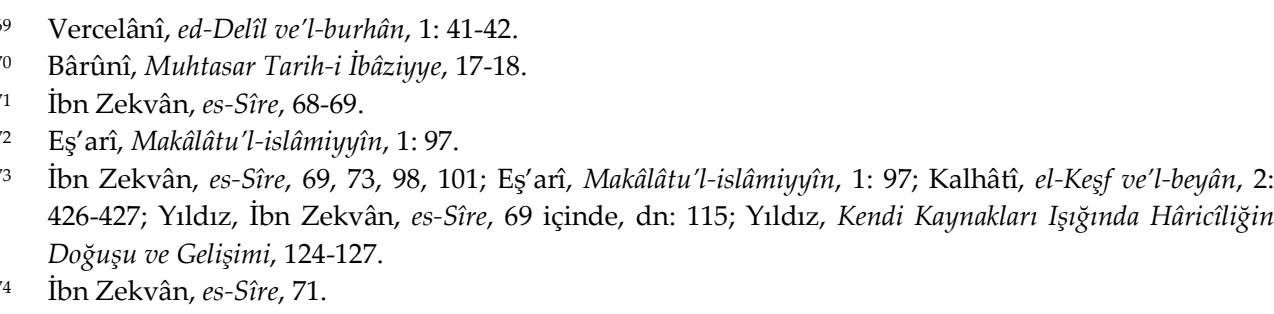


Haricîler, kavimleriyle miras hukukunu devam ettirmelerine rağmen kendileri ise tüm bağları koparmıştır. ${ }^{75}$ İbn Zekvân'a göre Ezârika bu davranışlarıyla ilk dönem Haricîlerinin uygulamalarıyla tamamen farklılaşmışlardır. Ona göre her hâlükârda bir problem vardır. Eğer kendileri haklıysa o zaman sevdikleri ilk Haricîler yanılmışlardır. Eğer sevdikleri Haricîler doğru davranmışlarsa o zaman kendileri yanlış yapmışlardır. ${ }^{76}$ İbn Zekvân onların yanlış uygulamalarından bazılarını zikretmiştir. Ona göre Allah'ın kelâmını dinlemek için kendilerine sığınanları reddetmekle Fussilet 26. ayete aykırı davranmışlardır. Yine namaz kılan, zekât veren, Allah'ın hükmünü uygulayan kişiler kendilerine geldikleri halde aralarına almamakla Tevbe 15. ayete aykırı davranmışlardır. ${ }^{77}$ İbâzîlerin kendilerinin Haricî olmadıklarına dair öne sürdükleri gerekçelerden birisi olan Ezârika'nın Kaade hakkındaki yaklaşımlarının, onların yanlışlıklarından birisi olduğunu zikrediyor. Ezârika, Kaade'yi kâfir saymakla ilk dönem Haricîlerinden farklı davranmışlardır. İbn Zekvân'a göre bu durumda da her iki taraftan birisinin hatalı olma ihtimali ortaya çıkar. Çünkü eğer Kaade Ehli, kâfir ise o zaman onlara dostluk gösteren ilk Haricîler de kâfir olmuş olurlar. ${ }^{78}$ İbn Zekvân Ezârika'nın bu yaklaşımın muhal olduğunu ortaya koymaya çalışmaktadır.

Ezârika'dan sonra Yemâme halkı arasında Necde b. Âmir ve taraftarları ortaya çıkmış ve onlar da kendi kavimlerini müşrik addetmişler, nikâhlanması haram kılınan müşrik kadınlarla evlenilmesini ve kurbanlarının yenilmesini helal saymışlardır. ${ }^{79}$ İbn Zekvân'a göre Necedât'ın, bağlı oldukları toplumun uygulamalarını terk etmeleri, kendilerinde cizye almadıkları müşrik kadınlarını nikâhlamaları, antlaşmalı topluluk eğer müşrik ise antlaşmalarına bağlı kalmaları, eğer müşrik değilse onları şirkle itham etmeleri, kendi toplulukların şirkle itham etmeleri onları saptırmıştır. ${ }^{80}$ Necedât fırkasının bu uygulamalarını bid'at olarak niteleyen İbn Zekvân'a göre onların kendi kavimlerine yönelik bu uygulamaları ilk Haricîlerin uygulamalarına uymamaktadır. O, Hz. Osman ve Hz. Ali'ye karşı çıkan Haricîler'in, bu tür davranışlar sergilemediklerini söyleyerek Necedat'ın ilk Haricîlerin takipçileri olmadıklarını ifade etmeye çalışmaktadır. ${ }^{81}$

Günümüz İbâzîleri de kendilerini Haricîlerden saymamalarına rağmen onların günümüzdeki yaşam şartlarına, düşünce yapılarına ve ibadet mekânlarına baktığımızda radikal söyleme sahip olmadıklarını; ama yine de Haricî zihniyetle yaşadıklarını söylememiz mümkündür. Mesela günümüz İbâzîleri hakkında bilgi veren Bârûnî'de Haricî zihniyeti çağrıştıran bir ötekileştirme dilinin olduğunu söylememiz mümkündür. Zira İbâzî ıstılahatında müspet anlamda kullanılan "imam" kelimesi ile kendilerince âdil olmayan kimseler için imam kelimesi yerine kullanılan "emir", "sultan" vb. lafızları kullandığını söyleyebiliriz. Örneğin üç milyon civarında İbâzînin yaşadığını söylediği Umân'da kâhir ekseriyetin âdil bir

\footnotetext{
İbn Zekvân, es-Sîre, 71.

İbn Zekvân, es-Sîre, 71.

İbn Zekvân, es-Sîre, 72.

İbn Zekvân, es-Sîre, 73.

İbn Zekvân, es-Sîre, 75.

İbn Zekvân, es-Sîre, 75.

1 İbn Zekvân, es-Sîre, 76.
} 
imam tarafından idare edildiğini, ama Maskat ve bazı sahil şehirlerin ise yine İbâzî olan sultan lakaplı emirin yönetiminde olduğunu ifade etmektedir. ${ }^{82}$ Günümüz İbâzîleri her ne kadar kendilerini Haricîlerden saymasalar da, İbâzîler Eş'arî gibi birçok fırak yazarı tarafından bizzat Haricîler olarak zikredilmişlerdir. Zaten kendisi İbâzî olan Şemmâhî, Nehrevân ehlinin tümünün İbâzî olduğunu ifade etmektedir. ${ }^{83} \mathrm{Bu}$ yaklaşım tarzı ve değerlendirmede Haricî zihniyet açıç̧a görülmektedir. Onun için ister eski isterse günümüz İbâzîleri her ne kadar kendilerinin Haricî olarak değerlendirilmesini istemiyorlarsa da zihniyetlerinin Haricî bir zihniyet olduğunu rahatlıkla söyleyebiliriz. İbazîlerin, Hz. Osman, Hz. Ali, tahkîm olayı vb. konularda Haricîlerin görüşlerini savundukları halde kendilerinin Haricî olarak isimlendirilmesine rıza göstermemeleri bir çelişkiden başka bir şey değildir. Zira aynı konularda aynı görüşte olmalarına rağmen kendilerini onlardan görmemeleri bir iddiadan öteye geçmemektedir.

Hz. Ali döneminde yaşanan tahkîm olayı neticesinde ortaya çıkan Haricî grup zamanla itikadî ve kelâmî görüşleriyle diğer kelâmî ekollerden farklı bir yaklaşım sergilemişlerdir. Haricî topluluğun devamında Ezârika ve Necedât gibi fırkalar neş'et ettiği gibi İbâziyye de bu topluluğun ardılları olarak neş'et etmiştir. Ama buna rağmen birçoğu kendilerinin Haricîlikle anılmasına karşı çıkmaktadırlar. İbâzîlerin içinde neş'et ettiği Haricîlerle örtüşen görüşleri çok olmakla birlikte onlardan farklı düşündükleri görüşleri de vardır. Farklı olan bazı görüşlerine rağmen diğer görüşlerinden hareketle İbâzîlerin Haricî bir fırka olduklarını söyleyebiliriz.

\section{1. İbâziyye'nin Haricîliğin Ezârika Koluyla Örtüşen Görüşleri}

İlk dönem makâlât eserlerinde İbâziyye'nin Haricîliğin bir alt kolu olarak zikredilmesi zamanla birçok İbâzî tarafında eleştirilmiştir. İbâzîler, kendilerinin Haricîlikle anılmasına karşı çıkmaktadırlar. Bu karşı çıkışlarına rağmen İbâzîliğin Haricîliğin bir alt kolu olduğuna dair birçok karine vardır. Bu hususta İbâzîler ile diğer Haricî kolların örtüşen birçok görüşlerinin olduğunu söylemek mümkündür. Kendileri gibi düşünenleri dost edinmek anlamına gelen tevellâ, kendilerinden saymadıkları kişilerden uzaklaşmak anlamına gelen teberrâ, küfür ehlinden saydıkları kişilere karşı cihada çıkmak anlamında kullandıkları huruç, iman, imâmet vb. birçok konuda benzer görüşlere sahip olduklarını söyleyebiliriz. İlk dönem Haricî ve Şiî literatüründe sıklıkla kullanılan kavram çiftlerinden olan tevellâ ve teberrâ kavramları İbâzîler tarafından da sıkça kullanılmaktadır. Teberrâ, isyankârlardan uzak durmak, Allah'a tövbe edinceye kadar onlardan uzak durup, onları yok hükmünde görmek anlamına gelmektedir. Tevellânın anlamı ise Allah'a itaat eden kişileri dost edinmek, onlar için istiğfarda bulunmak ve onları dünyevî işlerde desteklemektir. Tevellâ ve teberrâyı hem şahıslara hem de topluluklara karşı vacip gören günümüz Mizâbî İbâzîleri de seleflerinin uygulamalarını icra etmektedirler. ${ }^{84}$ Şunu da belirtelim ki Sâlim b. Zekvân, İbn

82 Bârûnî, Muhtasar tarih-i İbâziyye, 30.

83 Kâsım b. Süleyman b. Muhammed b. Ömer eş-Şemmâhî, el-Kavlu'l-metîn fi'r-red ala'l-muhâllifin, (y.y.: Matbaatu Mecelleti'l-Menâr, 1334/1915), 51.

84 Bârûnî, Muhtasar tarih-i İbaziyye, 73-74; Hizmetli, “İbâdilikte Velâyet ve Berâet İnancı”, 181-182. 
Sellâm, Kalhâtî, Vercelânî, en-Nizvânî ve daha birçok İbâzî âlim Allah'ın yasakladığ 1 fiilleri işleyenlerden teberrî ettiklerini ifade etmektedirler. ${ }^{85}$ Zaten bu görüşün Haricîlerin genel görüşü olduğu bilinmektedir. Bundan hareketle günümüz İbâzîleri de dâhil olmak üzere İbâziyye'nin bu konuda Haricî zihniyete sahip olduğunu söylememiz mümkündür. Yine onlar, Muvahhitlerden âsî olanların azaplarının her ne kadar kâfirlerden daha düşük derecede olduğunu söylüyorlarsa da onların da cehennemde ebedî kalacaklarına dair olan inançları; imanı, söz, tasdik ve âmelden ibaret görmeleri; şefaatin tövbe eden ve sözüne sadık kalanlar için olacağı şeklindeki düşüncelerinin Haricîlerin düşüncelerine benzer olduğunu söyleyebiliriz. ${ }^{86}$ İlk dönem İbâzîleri, Hz. Aişe, Talha ve Zübeyr gibi Cemel vak'asında yaptıklarından dolayı tövbe eden sahabiler hakkında olumlu kanaate sahip olmuşlar ve onlardan razı olmuşlardır. Ama kendilerine göre dinin zahirine aykırı davranıp ısrar eden ve bundan dolayı da tövbe etmeyen sahabelerden ise razı olmamışlardır. Müteahhirin İbâzîlerden bazıları ise bu hususta tevakkuf edilmesi ve bu konulara dalınmaması gerektiği görüşünde olmuşlardır. ${ }^{87}$ Bârûnî'ye göre Eş'arîler ise sahabenin tümünü ma'zûr görüyorlar ve hepsinden razıdırlar. Hz. Ali'ye karşı çıkan Muaviye ve taraftarlarına rıza gösterirlerken, Nehrevân ehlinde birçok sahabî olmasına rağmen onlara buğzetmişlerdir. Bârûnî, İmâm Ali'nin Nehrevândakilerin ölümü üzerine büyük bir pişmanlık duymasına rağmen Eş'arîlerin sahabe hakkındaki bu ayırımının büyük bir cahillik olduğunu ifade etmektedir. ${ }^{88}$ İbâzîlerin bu görüşlerinden hareketle onların sahabe hakkındaki yaklaşımlarının Haricîlerin yaklaşımı gibi olduğunu söyleyebiliriz.

İbâzîler'in Haricî bir fırka olduğuna dair en güçlü delillerden birisi de, onların Nehrevân ehli hakkındaki müspet değerlendirmeleridir. Daha önce de geçtiği üzere İbâzîler, din kavramı üzerinde çokça dururlar ve resmini çizmeye çalıştıkları dine uyanlar ile uymayanlar şeklinde bir tasnife giderek, insanlar hakkında kanaatlerini belirtirler. Örneğin Nehrevân ehlinin Muhakkime ve Şurât olduğunu vurgulayan en-Nizvânî́ye göre Nehrevân ehlinin uyguladığı din, zahirî hüküm itibariyle Hz. Ömer, Hz. Ebubekir, Hz Peygamber ve Allah Teâlâ'nın diniyle aynıdır ve aralarında herhangi bir fark da yoktur. Şurât ve Muhakkime'nin dini üzerine ölen kişi cennetliktir, ona muhalif olarak ölen kişi ise cehennemliktir. ${ }^{89} \mathrm{Bu}$ ifadelerde açıkça görüldüğü gibi en-Nizvânî, Nehrevân ehli, Muhakkime ve Şurât hakkında çok müspet bir yaklaşım sergilemekte ve buna muhalif bir şekilde ölen kişilerin ise cehennemlik olduğunu tereddütsüz bir şekilde ifade etmektedir. Çünkü ona göre Nehrevân ehlinin dinine muhalif olan kişiler, fâsık ve cahillerin

85 İbn Zekvân, es-Sîre, 97-98; İbn Sellâm el-İbâzî, Bedu'l-islâm ve şeraiu'd-dîn, 66-67, 94; Kalhâtî, el-Keş̧f ve'l-beyân, 2: 423,425; Vercelânî, ed-Delîl ve'l-burhân, 3: 180-186; Kâşif, "Mukaddime", el-Keşff ve'lbeyân, 1: 1 .

86 Vercelânî, ed-Delîl ve'l-burhân, 3: 180-181; Bârûnî, Muhtasar tarih-i İbaziyye, 73-74. İbâz'ilere göre tevellâ ve teberrâ'nın ne anlama geldiği ve kimler için gerçekleştiğiyle ilgili ayrıntılı bilgi için bk. Vercelânî, ed-Delîl ve'l-Burhân, 3: 180-186; Hizmetli, “İbâdilikte Velâyet ve Berâet İnancı”, 182-202.

87 Bârûnî, Muhtasar tarih-i İbaziyye, 75.

88 Bârûnî, Muhtasar tarih-i İbaziyye, 75-76.

89 en-Nizvânî, el-Cevheru'l-muktasar, 136. 
hükümlerine değil de Allah'ın hükmüne çağıran kişilere karşı çıkan kişilerdir. Öyle ki en-Nizvânî, Nehrevân ehline muhalif olarak ölen kişinin cehennemlik olduğuna dair şahitlikte bulunduklarını ifade etmektedir..$^{90}$ en-Nizvânî, Abdullah b. İbâz'ın ölünceye kadar yaşadığı din olan İbâziyye'nin dininin Muhakkime'nin, Şurât'ın ve Nehrevân ehlinin dini olduğunu ifade etmektedir. Ona göre bunların yolunu takip edenler, Hz. Ömer'in, Hz. Ebubekir'in, Hz. Resulullah'ın ve Allah'ın dinini takip etmişlerdir. Abdullah b. İbâz'ın dini üzerine ölen kişi cennetlik, ona muhalif olarak ölen kişi ise cehennemliktir. Çünkü İbâziyye'nin dini üzerine ölen kişi, sözüyle, ameliyle ve niyetiyle Allah Teâlâ'yı gerçek anlamda dost edinmiştir. Ona göre ancak sözüyle, ameliyle ve niyetiyle Allah Teâlâ'yı dost edinen kişi İbâzî dini üzerine ölmüş demektir. ${ }^{91} \mathrm{Bu}$ görüşlerden hareketle bu fikri benimseyen herkesin tartışmasız bir şekilde Haricî olduğunu söyleyebiliriz. Yine katı Haricîlerle İbâzîyye'nin büyük günah işleyen kişinin hukuku konusunda ihtilaf ettiklerini söylemek mümkündür. Buna karşllık tövbe etmeyen büyük günahkâra farklı sıfatlar verseler de cehennemlik olduklarını söyledikleri için itikadî noktada birleşmiş oluyorlar. Yukarıda aktardığımız hususlar, özellikle de İbâzîlerin Nehrevân ehli, Şurât ve Muhakkime'yi Hz. Ebubekir, Hz. Ömer, Hz. Resulullah ve Allah Teâlâ'nın dininin takipçileri oldukları şeklindeki değerlendirmeleri bu konu hakkındaki görüşümüzü açıklamaktadır. Bundan dolayı İbâzîliğin Haricîlik olduğunu, İbâzîlerin kabullenmedikleri ve onunla anılmasına karşı çıktıkları isimlendirmenin Ezârika olduğunu söylememiz mümkündür.

Haricîlikte sıkça kullanılan "huruç" kavramı İbâzîler tarafından da kullanılmaktadır. Örneğin ilk İbâzî âlimlerden İbn Zekvân kendilerini tavsif ederken bizzat, huruç kelimesini kullanmaktadır.92 İbâzîlerin Haricî olduğuna dair diğer güçlü delillerden birisi de İbn Zekvân'ın Hz. Ali dönemi olaylarını zikrederken ona karşı çıkıp sadece Allah'ı hakem kılanların "Müslümanların Haricîleri" ifadesini kullanmasıdır. O, Hz. Ali'ye karşı çıkanları Müslümanların Haricîleri şeklinde zikrederken bizzat "Havaric" lafzını kullanır. ${ }^{93}$ Kalhâtî döneminde de İbâzîlerin kendilerinin Müslümanlar anlamında Haricî ya da İslâm yolunda huruç edenler anlamında Haricî olarak isimlendirilmesini kabul ettikleri ifade edilmektedir. Aynı şekilde Sıffîn Vak'asında Hz. Ali ile birlikte Kûfe'ye girmeyi reddedip Harûra bölgesine çekilmelerinden dolayı kullanılan Harûriyye isminin, Şurât ve Muhakkime isimlerinin kendilerine verilmesini kabul ettikleri ifade edilmektedir. Yine Abdullah b. Vehb er-Râsibiyye'ye nisbetle Vehbiyye olarak da isimlendirildikleri ifade edilmektedir. ${ }^{94}$ Ayrıca Abdullah b. Vehb erRâsibi'nin Haricîlerin liderlerinden olduğunu belirtmemiz gerekir. ${ }^{95}$ Eş'arî, Haricîlerin kendilerinin Mârika ismi hariç Harûriyye, Şurât, Muhakkime

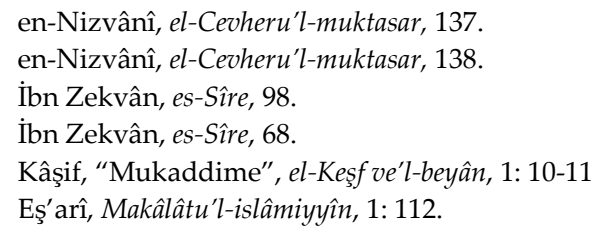


isimleriyle anılmalarına rıza gösterdiklerini aktarmaktadır. ${ }^{96}$ Kalhâtî, Hz. Ali'ye karşı çıkıp savaşan Nehrevân ehlini çok şiddetli bir şekilde savunmasına rağmen, Haricîlerdeki bozukluğu zikretmekte ve Ezârika başta olmak üzere istikamet ehli dediği kimselerden uzaklaşanlardan teberrî ettiğini ifade etmektedir. ${ }^{97}$

Küfrün imanın karşıtı olduğunu söyleyen İbâziyye'ye göre iman, Yüce Allah'ın söz, itikad ve amel hususunda emrettiği her şeydir. Küfür ise Yüce Allah'ın cehennem va'îdinde bulunduğu her şeydir.98 Ameli imanın bir parçası olarak gören İbâzî kelâmcı Vercelânî, bu hususta Mürcie'nin imanın kalpte ve dilde olan bir şey olduğu şeklindeki yaklaşımını eleştirmiştir.99 Aslında Vercelânî'nin, eleştirdiği Mürcie'nin iman tanımının, Eş'arî ve Mâturîdî kelâmcılar tarafından da savunulduğunu söylememiz mümkündür. Çünkü onlar da ef'al-i cevârih'i imandan saymazlar. Vercelânî'nin eleştirdiği hususun amelle ilgili olduğunu söyleyebiliriz. Zira Haricî zihniyet, ameli imandan bir cüz olarak görürken, Mürcie, Eş'ariyye ve Mâturîdîyye onu imandan bir cüz olarak görmez. Bundan dolayı İbâzîlerin iman tanımının Haricîlerin iman tanımı olduğunu söyleyebiliriz.

Netice itibariyle diyebiliriz ki Ezârika, Necedât ve Sufriyye gibi Haricîlerin literatüründe sıkça kullanılan tevellâ, teberrâ, huruç, iman, imâmet ve hilafet vb. kavramlar İbâzîler tarafından da benzer anlamda kullanılmaktadır. İbâzîlerin bu kavramlara yükledikleri anlamların diğer Haricî kolların kullandıkları anlamlarda olması, ilk dört halife döneminden itibaren neş'et eden olaylar hakkındaki değerlendirmeleriyle diğer Haricî kollarının değerlendirmelerinin benzer olması gibi hususlardan hareketle İbâzîlerin Haricî bir fırka olduğunu söylememiz mümkündür. Benzer görüşlere sahip olmakla birlikte İbâzîlerin diğer Haricî fırkalardan özellikle de Ezârika'dan iman, küfür, şirk vb. konularda farklı görüşlere sahip olduklarını söyleyebiliriz.

\section{2. İbâziyye'nin Haricîliğin Ezârika Kolundan Farklı Olan Görüşleri}

İbâziyye ile diğer Haricî fırkaların birbirleriyle örtüşen birçok görüşü olmasına rağmen farklılaşan görüşleri de vardır. Diğer Haricî fırkalarda olduğu gibi İbâziyye'de de küfür kavramı sıkça kullanılmaktadır. İbâzîler iman ve amel konusunda diğer Haricî fırkalarla benzer görüşlere sahip olmalarına rağmen küfür meselesinde onlardan farklı değerlendirmelerde bulunmaktadırlar. Zira İbâziler küfür kavramını diğer Haricî fırkalardan farklı bir şekilde kategorize etmektedirler. Küfr-ü şirk ve küfr-ü inkâr kavramlarını kullanmakla birlikte küfr-ü nimet ve küfr-ü nifâk kavramlarını da kullanmaktadırlar. Muvahhitlerin âsilerine karşı küfür kelimesini kullanırlar ve bununla da kâfir-i nimeti kastederler. Onlara göre muvahhitlerin âsileri küfr-ü nimet ve küfr-ü nifâk taifesindedirler. Haricîlerin Ezârika kolunda olduğu gibi İbâziyye'de de küfr-ü şirk ve küfr-ü inkârda ise kişi İslâm dininden çıkı kâfir olur. ${ }^{100}$ Örneğin, Muhakkime'yi dost edinen

96 Eş'arî, Makâlâtu'l-islâmiyyîn, 1: 109-110. İbâzîlerin Mârika eleştirisi için bk. Vercelânî, ed-Delîl ve'lburhân, 1: 43-44.

97 Kâşif, "Mukaddime”, el-Keşf ve'l-beyân, 1: 11. Krş. Kalhâtî, el-Keş̧f ve'l-beyân, 2: 239 vd, 421 vdğr.

98 Vercelânî, ed-Delîl ve'l-burhân, 3: 118-119.

99 Vercelânî, ed-Delîl ve'l-burhân, 3: 118.

100 Bârûnî, Muhtasar tarih-i İbâziyye, 74. 
İbâziyye'nin cumhuru, Muhakkime'ye muhalif olan kıble ehlinin küfre girdiğini, ama bu küfrün şirk küfrü olmadığını söylemişlerdir. ${ }^{101}$ İbâzîlerin bu konuda diğer Haricî fırkaların zihniyetine yakın olduğunu söyleyebiliriz. Zira küfür kavramını kullanmakla diğer Haricîlerle aynı görüşü benimsemektedirler. Ama küfr-ü şirk ve küfr-ü inkâr şeklinde değerlendirmeyerek onlardan farklı olduklarını söylememiz mümkündür. Şirk ehlini derecelendiren en-Nizvânî'ye göre âlemin kıdemini kabul eden Dehriyye ve Zenadıka birinci derecede şirk ehlidirler. Allah'ın bazı dinlerini kabul etmekle birlikte son peygamber Hz. Muhammed'in (a.s.) peygamberliğini inkâr eden Yahudiler, Hristiyanlar ve Zerdüştler ikinci derecede şirk ehlidirler. Üçüncü derecede şirk ehli olanlar ise Allah'ın dinini ikrar edip son peygamber $\mathrm{Hz}$. Muhammed'i (a.s) tasdik eden Ehl-i Kıble'den oldukları halde hak yoldan ayrılan ve Kur'an ile Sünnet'i kötü bir şekilde te'vil edenlerdir. en-Nizvânî'ye göre bunlar yetmiş iki fırkadırlar ve din ehlinin hükümleri kendilerine uygulanır. Bu görüşüne rağmen ona göre İbâzîlerin takip ettikleri yolun haricindeki yolu ısrarlı bir şekilde takip edenler hakirdirler, rezildirler ve cehennemde ebedî olarak kalacaklardır. ${ }^{102}$ İlk İbâzî âlimlerden İbn Zekvân, kıblelerine döndükleri sürece kavimlerindekileriyle nikâhlanmayı, onlara vâris olmayı kendilerine haram kılmadıklarını ifade etmektedir. ${ }^{103}$ Bu konuda Eş'arî de benzer aktarımlarda bulunmaktadır. Ona göre İbâzîler de diğer Hâricîlerin yaptıkları gibi muhalifleriyle nikâhlanmayı, mirasçı olmayı ve mallarının ganimet alınmasını helal addetmektedirler; ama bunun dışındaki uygulamaları ise haram saymaktadırlar. Örneğin şirke çağırmadıkları sürece onları gizliden gizliye öldürmeyi ve muhaliflerini dinlerine çă̆ırmadıkça kanlarını akıtmayı haram görmektedirler. ${ }^{104} \mathrm{Ne}$ var ki İbn Zekvân'ın bu konu hakkındaki gerekçesi ise farklı problemleri barındırmaktadır. Çünkü o, kendi topluluğundakilerin durumunu münafıkların durumuna benzetmektedir. İbn Zekvân, Müslümanlar Münafıkların durumunu bildikleri halde onlarla evlenip onlara mirasçı olduklarını söyleyerek yaptıklarını meşrulaştırmaya çalışmaktadır. ${ }^{105}$ Yine kıblelerine döndükleri sürece hiç kimseye zina suçunda bulunmadıklarını; ama birçok Haricînin ise kendilerinden uzaklaşanlara karşı bile bile zina iftirasında bulunmayı helal gördüklerini ifade etmektedir. ${ }^{106}$

İbâzîlerin Ezârika'dan farklı düşündükleri meselelerden birisi de isti'raz ve kaade hakkındaki değerlendirmeleridir. İbn Zekvân gibi ilk dönem İbâzî âlimlerden, Kalhâtî ve diğer birçok âlimlerine kadar İbâzîler davetten önce isti'razı uygun görmemektedirler ve kaade'den teberrî etmemektedirler, hatta onları dost edindiklerini ifade etmektedirler. ${ }^{107}$

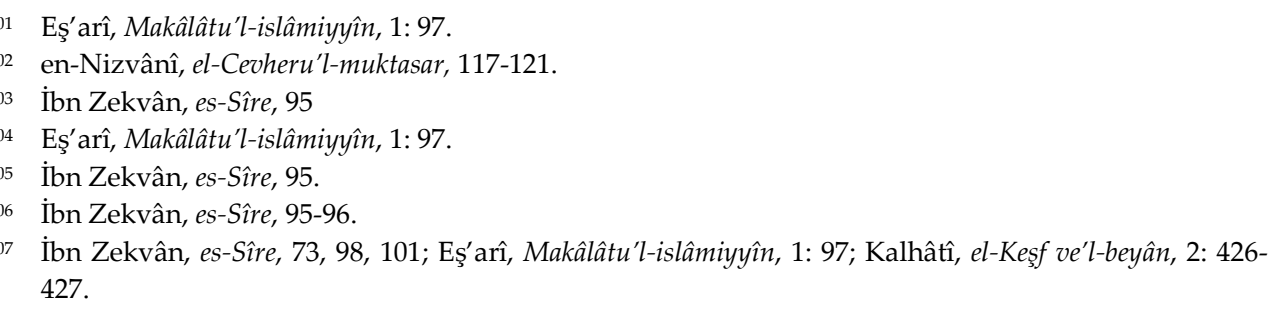


Sonuç olarak İbâzîlerin iman, amel, tevellâ ve teberrâ gibi birçok konuda Ezârika ile ayn görüşleri benimsemekle birlikte isti'raz, şirk, küfür, kaade vb. konularda ise onlardan farklı düşündüklerini söyleyebiliriz.

\section{Sonuç}

Hz. Ali döneminde gerçekleşen tahkîm olayı neticesinde neş'et eden Haricî topluluk zamanla Ezârika, Necedât, Sufriyye ve İbâziyye gibi farklı kollara ayrılmıştır. İbâzîler diğer Haricî fırkalar gibi kendilerini Haricîlerin ilk nüvesi olan el-Muhakkimetu'l-Ûlâ'nın devamı olarak görmektedirler. Ancak marjinal olarak değerlendirdikleri Ezârika ve diğer Haricî fırkalarla ve hatta Haricîlikle bile anılmalarına sıcak bakmamaktadırlar. Kendilerinin Ehl-i İstikamet olduklarını ve diğer Haricî fırkalarla herhangi bir irtibatlarının olmadığını iddia etmektedirler.

İbâzîler, diğer Haricî fırkalar gibi Hz. Ebubekir ve Hz. Ömer dönemlerini olumlu bir şekilde değerlendirirken Hz. Osman'ın son altı yıllık dönemini ve Hz. Ali'nin tahkîm olayı sonrası dönemini ise olumsuz bir dille değerlendirmektedirler. İbâzîler her ne kadar kendilerinin Haricilikle zikredilmelerine karşı çıkıyorlarsa da imâmet ve hilâfet, tevellâ ve teberrâ, iman ve amel gibi birçok konuda Haricîlerle benzer görüşleri savunmaktadırlar. Ama isti'raz, kaade hakkındaki yaklaşım, küfür ve şirk meselelerinde ise diğer Haricî fırkalardan farklı değerlendirmelerde bulunmaktadırlar. Buna benzer konularda farklı düşünmelerine rağmen diğer Haricîlerle birçok konuda benzer görüşlere sahip olduklarını söylemek mümkündür. Bu ortak görüşlerine rağmen birçok İbâzî, kendilerinin Haricîlikle anılmalarına karşı çıkmaktadır. İbâzîlerin biz Haricî değiliz iddialarının gerçeklikle bir bağlantısının olmadığını söylememiz mümkündür. Zira ilk dönem İbâzî âlimlerinden Sâlim b. Zekvân ve ondan sonraki birçok İbâzî düşünür, Ezârika'ya kadar olan Haricîleri ve onların uygulamalarını meşru görmektedirler. Şunu rahatlıkla ifade edebiliriz ki İbâzîlerin karşı çıktıkları gruplar, kendileri gibi Haricîlerin alt kollarından olan Ezârika ve Necedat'tır. Bundan dolayı İbâzîlerin, Ezârika Necedat ve Sufriyye'nin kendilerinden önceki "Müslüman Haricîlerin" yolundan ayrılarak marjinal görüşleri benimsediklerini; ama kendilerinin ise ilk Haricîlerin görüşlerini takip ettikleri düşüncesinde olduklarını söylememiz mümkündür.

Netice itibariyle birçok İbâzînin, kendilerinin Haricîlikle zikredilmelerine karşı çıkmalarına rağmen aralarındaki ortak kanaat ve uygulamalarından hareketle İbâzîlerin diğer Haricî fırkalar gibi marjinal görüşlere sahip olmayan mu'tedil bir Haricî fırka olarak günümüze kadar varlıklarını devam ettirdiklerini söyleyebiliriz. İbâzîler, Ezârika gibi aşırı Haricî gruplardan büyük günahkârın dünyadaki konumu, hukuku ve dini nitelikleri bakımından ayrılmaktadırlar. Dikkat çeken diğer önemli bir husus ise onların kendi mezheplerini din olarak telakki ederek kendilerinin dışındaki diğer mezheplerin ise dinden çıktıklarını ve cehennemlik olduklarını iddia etmeleridir. Diğer taraftan Haricîlik siyasî ve itikadî bir fırka olduğu için, İbâzîler, Muhakkime'nin ve Nehrevan Ehli'nin tutumunu meşru saydıkları, muhalifleri ise cehennemlik olarak gördükleri için, başka hiçbir şart aramaya ihtiyaç duymadan bir Haricî fırkası olarak görülebilirler. 


\section{Kaynakça}

Abdulhamid, İrfan. Dırâsât fi'l-firaki'l-akâidi'l-islâmiyye. Bağdat: Matbaatu'l-İrşâd, 1967.

Ateş, Orhan. "İbaziyye Haricî Bir Firka mıdır?". Avrasya Sosyal ve Ekonomi Araştırmaları Dergisi 17/1 (Ocak 2017): 1-23.

Ateş, Orhan. "Salim b. Zekvân'ın Sîre'sinde Hz. Osman'la İlgili Kısmın İbâzî Fikirler Açısından Değerlendirilmesi" Çukurova Üniversitesi İlahiyat Fakültesi Dergisi 9/2 (Aralık 2009): 99-114.

Bahhâz, İbrahim. "Mu'tezilî Mizâbîler". Trc. Adem Arıkan. İslâmî İlimler Dergisi 12/2 (2017): 179-190.

Bağdâdî, Abdulkâhir b. Tâhir. el-Fark beyne'l-firak ve beyânu'l-firkati'n-nâciye minhum. Thk. Licnetu İhyâi't-Turâsi'l-Arabî fî Dâri'l-Âfâki'l-Cedîd. Beyrût: Menşurâti'l-Dâri'l-Âfâki'l-Cedîd, 1982.

Bârûnî, Ebû Rebî' Süleyman. Muhtasar tarih-i İbâziyye. y.y.: Mektebetu'd-Dâmirî, 1995.

Erdemci, Cemalettin. İbn Sellam el-i̇bâdî ve İtikadi Görüşleri. Yüksek Lisans Tezi Yüzüncü Yıl Üniversitesi, 1996.

es-Sa'dî, Cumeyyil b. Hamîs b. Lâfî b. Hilfan b. Hamîs. Kamusu'ş-şeri'a el-Hâvî Turukuhe'l-Vesî'ah. 5 Cilt. Umân: Vizâretu't-Turâsi'l-Kavmî ve's-Sekâfe, 1983.

es-Salihi, Azmi M. S. - Öz, Mustafa. "Hariciler". Türkiye Diyanet Vakfi İslâm Ansiklopedisi. 16: 175-178, İstanbul: TDV Yayınları, 1997.

Eş'arî, Ebu'l-Hasan Ali b. İsmail. Makâlâtu'l-islâmiyyîn ve ihtilâfu'l-musallîn. Nşr. Naîm Zerzûr. 2 Cilt. Beyrût: Mektebetu'l-Asriyye, 2005.

Hizmetli, Sabri. "İbâdilikte Velâyet ve Berâet İnancı". Ankara Üniversitesi İlahiyat Fakültesi Dergisi 28 (1986): 180-204.

F1ğlalı, Ethem Ruhi. "İbâdiye'nin Siyasî ve İtikadî Görüşleri”. Ankara Üniversitesi İlahiyat Fakültesi Dergisi 21 (1976): 323-344.

Fığlalı, Ethem Ruhi. "Hariciler", Türkiye Diyanet Vakfı İslâm Ansiklopedisi.16: 169175, İstanbul: TDV Yayınları, 1997.

Fığlalı, Ethem Ruhi. "İbâziye”, Türkiye Diyanet Vakfı İslâm Ansiklopedisi. 19: 256-261. İstanbul: TDV Yayınları, 1999.

İbn Sellâm el-İbâzî. Bedu'l-islâm ve şeraiu'd-dîn, Beyrut: Wiesbaden, 1986.

İbn Zekvân, Sâlim. es-Sîre Bir HâricîlIbâdı̂ Klasiği. Trc. Harun Yıldız. Ankara: Ankara Okulu Yayınları, 2016.

Kalhâtî, Ebû Abdillah Muhammed b. Said el-Ezdî. el-Keşf ve'l-beyân. Tahkik ve Şerh eden: Seyyide İsmail Kâşif. 2 Cilt. Y.y.: Metâbi' Sicili'l-Arab, 1980. 
Kâşif, Seyyide İsmail. "Mukaddime". el-Keşf ve'l-beyân. Tahkik ve Şerh eden: Seyyide İsmail Kâşif. 2 Cilt. Y.y.: Metâbi' Sicili'l-Arab, 1980.

Keskin, Mehmet. İmam Eş'ar̂̂ ve Eş'arilik. İstanbul: Düşün Yayıncılık, 2013.

Kutluay, Yaşar, “İbâdîlere Ait Bazı Metinler”, AüİFD 15 (1967): 141-149.

Muammer, Ali Yahya. el-İbaziyye beyne'l-Frraki'l-İslâmiyye İnde Küttâbi'l-Makâlât fi'lKadîm ve'l-Hadîs. 2. Baskı. 1 Cilt. Y.y: b.y., 1994.

Muammer, Ali Yahya. el-İbâziyye Mezhebun İslâmiyyun Mu'tedilun. 2. Baskı. Y.y.: Vizâretu'l-Evkâf ve'ş-Şuûni'd-Diniyye Mektebetu'l-İfta', 1979.

Madelung, Wilferd. "Eş'arî Öncesi Kelâma Şiî ve Haricî Katkı". Trc. Süleyman Akkuş. Sakarya Üniversitesi Illahiyat Fakültesi Dergisi 15 (2007): 161-184.

Mezâtî, Ebû Ali er-Rabî' b. Yahlef. et-Tuhefu'l-mahzune fì icmâi'l-usûli'ş-şer'iyye ve meânîhâ. Thk. Mahmûd el-Endülüsî. Y.y: b.y., 2009.

Nizvânî, Ebubekir Ahmed b. Abdillah b. Mûsâ el-Kindî. el-Cevheru'l-muktasar. Thk. Seyyide İsmail Kâşif. Kahire: Umân Milli Miras ve Kültür Bakanlığı Yayınları, 1983.

Öz, Mustafa. "İsti'raz”, Türkiye Diyanet Vakfı İslâm Ansiklopedisi. 23: 374, İstanbul: TDV Yayınları, 2001.

Öz, Mustafa. "Kaade", Türkiye Diyanet Vakfı İslâm Ansiklopedisi. 23: 589, İstanbul: TDV Yayınları, 2001.

Söylemez, Mehmet Mahfuz. "Mahfuzat: Cezayir İbâdîleri Arasında Beş Gün", İslami İlimler Dergisi 10/1, (Bahar 2015): 169-185.

Şemmâhî, Kâsım b. Süleyman b. Muhammed b. Ömer. el-Kavlu'l-metîn fi'r-red ala'lmuhâllifinn. Y.y.: Matbaatu Mecelleti'l-Menâr, 1334/1915.

Şehristânî, Ebu'l-Feth Muhammed b. Abdi'l-Kerîm Ebî Bekr Ahmed. el-Milel ve'nnihel, Thk. Emîr Ali Mehnâ- Ali Hasan Fâğûr. 2 Cilt. Beyrût: Dâru'l-Ma'rife, 1994.

Uysal, Ekrem. "Ehl-i Sünnet ve Mu'tezile'ye Göre Kesb Nazariyesi". Batman Üniversitesi İslami İlimler Fakültesi Dergisi 2/1, (2018), 39-51.

Vercelânî, Ebû Ya'kub Yusuf İbrahim. ed-Delîl ve'l-burhân. Thk. eş-Şeyh Sâlim b. Hamdu'l-Hârisî. 3 Cilt. Maskat: Vizâretu't-Turâsi'l-Kavmî ve's-Sekâfe, 2006.

Werner Schvartz. eş-Şeyh Sâlim b. Ya'kub. "Mukaddime". Bedu'l-İslâm ve Şeraiu'dDîn, Beyrut: Wiesbaden, 1986.

Yıldız, Harun. Kendi Kaynakları Işı̆̆ında Hâricîliğin Doğuşu ve Gelişimi. Ankara: Araştırma Yayınları, 2010.

Yıldız, Harun. "Sâlim b. Zekvân ve es-Sîre Adlı Eseri". İbn Zekvân, Sâlim. es-Sîre Bir Hâricîlibâdı̂ Klasiğgi. Trc. Harun Yıldız. Ankara: Ankara Okulu Yayınları, 2016. 
Yıldız, Harun. "Ali Yahya Muammer'in Çalışmalarında İbadilik". e-Makâlât Mezhep Araştırmaları 8/1 (Bahar 2015): 7-51.

Yıldız, Harun. "Haricî Düşüncenin Gelişimi”. OMÜİFD 11 (1999): 257-270. 